\title{
Application of Biosensors for Detection of Pathogenic Food Bacteria: A Review
}

\author{
Athmar A. Ali ${ }^{1}$, Ammar B. Altemimi ${ }^{1}{ }^{1}$, Nawfal Alhelfi ${ }^{1}$ and Salam A. Ibrahim ${ }^{2, *}$ \\ 1 Department of Food Science, College of Agriculture, University of Basrah, Basrah 61001, Iraq; \\ athmar.ali93@gmail.com (A.A.A.); ammaragr@siu.edu (A.B.A.); nawfalalhelfi@gmail.com (N.A.) \\ 2 Food and Nutritional Science Program, North Carolina A \& T State University, Greensboro, NC 27411, USA \\ * Correspondence: ibrah001@ncat.edu
}

Received: 28 April 2020; Accepted: 27 May 2020; Published: 30 May 2020

\begin{abstract}
The use of biosensors is considered a novel approach for the rapid detection of foodborne pathogens in food products. Biosensors, which can convert biological, chemical, or biochemical signals into measurable electrical signals, are systems containing a biological detection material combined with a chemical or physical transducer. The objective of this review was to present the effectiveness of various forms of sensing technologies for the detection of foodborne pathogens in food products, as well as the criteria for industrial use of this technology. In this article, the principle components and requirements for an ideal biosensor, types, and their applications in the food industry are summarized. This review also focuses in detail on the application of the most widely used biosensor types in food safety.
\end{abstract}

Keywords: biosensors; pathogenic bacteria; bioluminescence; ATP; foodborne

\section{Introduction}

Many people around the world become ill each year by consuming food pathogens. These foodborne illnesses are highly correlated to both physical and chemical contamination of foods in addition to the presence of pathogenic microorganisms [1,2]. A number of authors have reported that food contamination caused by microorganisms could be attributed to the natural contamination that occurs in raw materials [3] or the cross-contamination of foods due to different contaminated sources such as air, water, hair, dirt, animal feces, humans, infected wounds, etc. [4].

Microbial pathogens can contaminate foods and cause foodborne diseases [5]. The Centers for Disease Control and Prevention (CDC) in the United States has stated that either foodborne or waterborne pathogens are considered to be the primary causative factors in 76 million cases each year for foodborne illnesses in the United States alone [6]. The percentage of pathogenic bacteria, parasites, and viruses was five million cases, two million cases, and thirty million cases, respectively $[7,8]$.

Multiple conventional tests were applied to detect microbial contaminants in foods, surfaces, utensils, and equipment. These tests included the following: viable cell counting [9], staining [10], carbohydrate fermentation assay, enzyme linked immunosorbent assay [11], polymerase chain reaction [12], ultraviolet detection [13], and fluorescence techniques [14]. Despite the development of many analytical techniques using automated and complex instrumentation for monitoring and detecting the biological contaminants in foods, there are still several drawbacks and limitations to using these traditional approaches [8]. For example, these traditional approaches require large numbers of samples, high skill levels, and are time consuming and costly $[15,16]$. In addition, most traditional methods require a long time to obtain accurate microbiological results [17]. Consequently, in the past few years, a lot of developed and rapid in situ methods were investigated as an alternative to the 
existing microbiological approaches. These methods were highly sensitive to count and evaluate food contamination as well as the degree of cleaning and sanitizing of food contact surfaces [18].

Biosensors represent one such innovative method that has been developed to overcome some major problems regarding food sample analysis. Moreover, the use of biosensors to monitor and provide rapid real-time information will be superior compared to traditional microbiological approaches [19]. Adenosine triphosphate (ATP) bioluminescence, a highly effective biosensor, can be used for food process manufacture monitoring such as HACCP (hazard analysis and critical control points) $[20,21]$. Bioluminescence is the mechanism of light emission from organisms and thereby reflects the chemical conversion of energy into light. The ATP bioluminescence test is since ATP is a significant biological source of energy found in various microbes and thus represents the presence of a living microbe [22].

Biosensor technology was developed to be a useful indicator of bacterial contamination on food and food contact surfaces. In this review, we present the effectiveness of various forms of sensing technologies for the detection of foodborne pathogens in food products, as well as the criteria for industrial use of this technology. This review will also focus in detail on the application of the most widely used biosensor types in food safety.

\section{Foodborne Pathogens}

In recent years, the demand for enhanced food security has gradually increased. As reported in the media and other sources, diseases caused by bacterial contamination represent about $40 \%$ in all infections, and the diseases due to foodborne pathogenic have a significant effect on the health of the population as a whole as well as the economy [23].

Foodborne illnesses thus represent an enormous challenge to worldwide health care systems [24]. For example, in the US, about 48 million individuals suffer from foodborne illnesses each year resulting in around 128,000 hospitalizations, 3000 deaths, and \$15.6 billion in economic losses [25]. Because human food and water sources can be easily contaminated by a broad spectrum of microbial pathogens, serious illness results if these microbial pathogens or their toxins are consumed [26]. Bacteria, viruses, and parasites are the most prevalent pathogens that cause foodborne diseases [27,28], but fungal foodborne diseases are also identified [29]. Bacteria are the most well-known foodborne pathogen, and cause the greatest number of foodborne illnesses, including the most hospitalizations (63.9\%) and deaths (63.7\%) [25]. Bacterial contamination can cause repeating intestinal irritation, kidney disease, mental incapacity, receptive joint inflammation, visual impairment, and even death [30]. In addition, foodborne diseases can occur because of toxins produced either from bacteria or fungi, which may survive even after food processing. Foods that are raw, including meat and poultry or vegetables, fruits, eggs, dairy products, and even cooked seafood, can be contaminated with both foodborne pathogens and their toxins [31-33]. Examples of foodborne diseases caused by pathogens in the food matrix are shown in Table 1.

Table 1. Examples of Foodborne Diseases Caused by Microorganisms in the Food Matrix.

\begin{tabular}{|c|c|c|c|}
\hline Pathogenic Sources & Food Matrix & $\begin{array}{l}\text { Symptoms and } \\
\text { Illnesses }\end{array}$ & References \\
\hline Staphylococcus aureus & $\begin{array}{l}\text { Unpasteurized Milk and } \\
\text { Cheese Products }\end{array}$ & Food Poisoning & $\begin{array}{l}\text { Khare et al. [34] } \\
\text { Mostafa et al. [35] }\end{array}$ \\
\hline Bacillus cereus & $\begin{array}{l}\text { Dairy Products, Dry } \\
\text { Foods, Rice, Egg } \\
\text { Products }\end{array}$ & Diarrhea, Vomiting & $\begin{array}{l}\text { Grutsch et al. [36] } \\
\text { Griffiths and Schraft [37] }\end{array}$ \\
\hline E. coli O157:H7 & Meat Products and Milk & $\begin{array}{l}\text { Diarrheal Diseases and } \\
\text { Producing of } \\
\text { Shiga Toxins }\end{array}$ & $\begin{array}{c}\text { Xu et al. [38] } \\
\text { Kramarenko et al. [39] }\end{array}$ \\
\hline Vibrio parahaemolyticus & Seafood & Diarrhea & $\begin{array}{c}\text { Letchumanan et al. [40] } \\
\text { Jiang et al. [41] }\end{array}$ \\
\hline
\end{tabular}


Table 1. Cont.

\begin{tabular}{|c|c|c|c|}
\hline Pathogenic Sources & Food Matrix & $\begin{array}{l}\text { Symptoms and } \\
\text { Illnesses }\end{array}$ & References \\
\hline E. coli $\mathrm{O} 26$ & Ground Beef & $\begin{array}{c}\text { Stomach Cramps, Bloody } \\
\text { Diarrhea, Vomiting and } \\
\text { High Fever }\end{array}$ & $\begin{array}{c}\text { Ma et al. [42] } \\
\text { Amagliani et al. [43] }\end{array}$ \\
\hline Salmonella enteritidis & $\begin{array}{l}\text { Meats, Eggs, Fruits, } \\
\text { Vegetables }\end{array}$ & $\begin{array}{l}\text { Vomiting, Diarrhea, } \\
\text { Cramps, Fever }\end{array}$ & $\begin{array}{c}\text { Sharma [44] } \\
\text { Paramithiotis et al. [45] }\end{array}$ \\
\hline $\begin{array}{l}\text { Vibrio parahaemolyticus } \\
\text { Vibrio cholerae }\end{array}$ & $\begin{array}{l}\text { Freshwater Fish } \\
\text { and Shellfish }\end{array}$ & Severe Diarrhea, Cholera & $\begin{array}{c}\text { Li et al. [46] } \\
\text { Baron et al. [47] }\end{array}$ \\
\hline Klebsiella pneumoniae & $\begin{array}{l}\text { Fresh Fruits and } \\
\text { Vegetables }\end{array}$ & Pneumonia & $\begin{array}{l}\text { Mesbah Zekar et al. [48] } \\
\text { Ghafur et al. [49] }\end{array}$ \\
\hline Campylobacter jejuni & Meat, Poultry & $\begin{array}{c}\text { Postinfectious Reactive } \\
\text { Arthritis }\end{array}$ & $\begin{array}{c}\text { Riley [50] } \\
\text { Skarp et al. [51] }\end{array}$ \\
\hline Clostridium perfringens & Poultry Meat & $\begin{array}{c}\text { Human Gastrointestinal } \\
\text { Diseases }\end{array}$ & $\begin{array}{l}\text { Hamad et al. [52] } \\
\text { Rouger et al. [53] }\end{array}$ \\
\hline Clostridium botulinum & $\begin{array}{l}\text { Uncooked Food, } \\
\text { Canned Foods }\end{array}$ & Botulism & $\begin{array}{l}\text { Aston and Beeching [54] } \\
\text { Yadav et al. [55] }\end{array}$ \\
\hline Listeria monocytogenes & Lentil Salad & $\begin{array}{l}\text { Gastroenteritis and } \\
\text { Invasive Infection }\end{array}$ & $\begin{array}{c}\text { Drali et al. [56] } \\
\text { Vojkovska et al. [57] }\end{array}$ \\
\hline Shigella sp. & Poor Water Supply & $\begin{array}{l}\text { Watery Diarrhea Mixed } \\
\text { with Blood and Mucous }\end{array}$ & $\begin{array}{l}\text { Nisa et al. [58] } \\
\text { Shafqat et al. [59] }\end{array}$ \\
\hline hepatitis E virus & Rabbit Meat & Liver Disease & $\begin{array}{l}\text { Bigoraj et al. [60] } \\
\text { Kaiser et al. [61] }\end{array}$ \\
\hline Salmonella & Fresh Vegetables & Gastroenteritis & $\begin{array}{l}\text { Yang et al. [62] } \\
\text { Saw et al. [63] }\end{array}$ \\
\hline
\end{tabular}

\section{Monitoring of Microorganism Activities in the Food Matrix}

A successful microbiological environmental surveillance system can provide early warning of possible microbiological hazards in food items, detect problems, and thereby support comprehensive microbiological safety. Thus, for several decades, the microbiological aspects of food safety have been intensively examined. For example, maintaining food protection has always been a very critical aspect of government policies in some countries. Management systems have been set up to prevent harmful contaminants from being introduced into the food chain [8]. According to the Centers for Disease Control and Prevention (CDC), the influence of microorganisms such as bacteria, viruses, and fungi on human life is worthy of significant attention [22]. The implementation and monitoring of microbial food safety contributes to enhanced productivity, higher wages, sustainable development, and better livelihoods, which is why it has been suggested that policy makers implement appropriate food safety policies in order to enhance global nutrition and improved food security [64].

Microbial food safety is radically different from chemical food safety. Although chemical contaminants and additives usually join the food chain at predetermined levels, microbes may join at any point [65]. Consequently, food regulations everywhere are very straightforward on this level. For instance, the EU General Food Law [66] states: "a high level of protection of human life and health should be assured in the pursuit of community policies". The microbiological safety of consumer products is also closely linked to the hygienic properties of the manufacturing system. Under these conditions, the implementation of adequate sanitation methods is essential for the protection of the final product. Evaluation of the efficacy of such methods is important for the assurance of these procedures [67]. In fact, all food safety regulations require these inspection activities. Researchers are therefore making considerable efforts to establish rapid and effective methods to meet the requirements of daily investigation and monitoring of food production [67]. 
The requirement of monitoring contamination in the food chain involves several analytical methods and the use of sophisticated and automated instrumentation that has been recently developed for detection of contaminants in food [68]. However, there are still many drawbacks and limitations to using these traditional approaches [8]. Furthermore, diagnostic tools must be capable of assessing feasibility and flexible enough to identify the pathogen of concern. Table 2 shows a list of some microbiological analysis approaches used to monitor food safety.

Table 2. Examples of Microbiological Analysis Approaches for Monitoring Food Safety.

\begin{tabular}{|c|c|c|c|}
\hline $\begin{array}{l}\text { Microbiological } \\
\text { Approaches }\end{array}$ & $\begin{array}{l}\text { Detection Limit } \\
\text { (Log CFU/mL) }\end{array}$ & Time Consumed & References \\
\hline Viable Cell Counting & Unlimited & days & $\begin{array}{c}\text { Rajapaksha et al. [9] } \\
\text { González-Ferrero et al. [69] }\end{array}$ \\
\hline Microscopy & Unlimited & $\min$ & $\begin{array}{l}\text { Sakamoto et al. [70] } \\
\text { Mobed et al. [71] }\end{array}$ \\
\hline Absorbance & $8-9$ & Immediate & $\begin{array}{l}\text { Hazan et al. [72] } \\
\text { Ikonen et al. [73] }\end{array}$ \\
\hline $\begin{array}{l}\text { Enzyme Linked } \\
\text { Immunosorbence }\end{array}$ & $2.83-3$ & $3 \mathrm{~h}$ & $\begin{array}{c}\text { Shen et al. [74] } \\
\text { Preechakasedkit et al. [75] }\end{array}$ \\
\hline $\begin{array}{c}\text { Staining with } \\
\text { Fluorescence Dyes }\end{array}$ & $3-4$ & $26 \mathrm{~min}$ & $\begin{array}{c}\text { Guo et al. [76] } \\
\text { Annenkov et al. [77] }\end{array}$ \\
\hline Start Growth Time & $1.60-2.60$ & $\mathrm{~h}$ & Hazan et al. [72] \\
\hline Flow Cytometry & $4-8$ & $\mathrm{~h}$ & $\begin{array}{c}\text { Ou et al. [78] } \\
\text { Adan et al. [79] }\end{array}$ \\
\hline $\begin{array}{l}\text { Methylene Blue Dye } \\
\text { Reduction Test }\end{array}$ & 7 & $\mathrm{~h}$ & $\begin{array}{l}\text { Bapat et al. [80] } \\
\text { Pawar et al. [81] }\end{array}$ \\
\hline $\begin{array}{c}\text { Isothermal } \\
\text { Microcalorimeters }\end{array}$ & $>2$ & $5-7 \mathrm{~h}$ & $\begin{array}{l}\text { Fricke et al. [82] } \\
\text { Broga et al. [83] }\end{array}$ \\
\hline $\begin{array}{c}\text { Laser-Induced Breakdown } \\
\text { Spectroscopy (LIBS) }\end{array}$ & 1 & $3 \mathrm{~min}$ & $\begin{array}{l}\text { Multari et al. [84] } \\
\text { Moncayo et al. [85] }\end{array}$ \\
\hline $\begin{array}{c}\text { Fourier Transform Infrared } \\
\text { (FT-IR) Spectroscopy }\end{array}$ & 5.3 & $60 s$ & $\begin{array}{l}\text { Ellis et al. [86] } \\
\text { Johler et al. [87] }\end{array}$ \\
\hline Nanoprobe-ATP & $2-6$ & $20 \mathrm{~min}$ & Xu et al. [88] \\
\hline
\end{tabular}

\section{Biosensors}

Leland Charles Clark Jr. designed the first biosensor research instrument in 1956 using an electrode to measure the oxygen concentration in blood. After that, scientists from different fields, such as physics, chemistry, and material science, have come together to build more sophisticated, reliable, and mature biosensing devices for applications in the field of medicine [89]. Several approaches using innovative techniques for pathogen enumeration and identification in perishable and semi-perishable foods have been identified in the last few years. In most microbiological research, quantification of bacterial cells is necessary. Therefore, seeking cost-effective techniques with several properties is required, namely high sensitivity, specificity, and fast responses [70,90].

The word biosensor refers to an effective and creative analytical device that has a biological sensing function with a broad variety of applications such as food safety, environmental monitoring, biomedicine, and drug discovery [91]. More specifically, biosensors are widely used in the identification and detection of bacteria and have attracted great interest as one of the most efficient and accurate methods of food analysis and food safety monitoring [92-94]. In addition, biosensors typically deliver fast, on-site tracking and thus provide real-time details throughout the production process $[95,96]$. Biosensors are thus another broad class of bacteria detection method. For example, conductometric measurements provide fast and simple bacterial detection [97]. 
Because biosensors are analytical devices for the detection of microbial contamination, their function depends on the interaction between biologically active agents, the transducer, and a signal conversion unit [98,99]. Mayer and Baeumner [100] clarified that biosensors typically contain two main components: a target recognition component such as receptors, nucleic acids, or antibodies and a signal transducer that transforms target recognition into physically detectable signals. The internal reflection, fluorescence resonance energy transfer (FRET), chemiluminescence, bioluminescence, and surface plasmon resonance (SPR) have been employed as manufacturing optical transducers in the fabrication of biosensors [8]. In general, biosensors may be divided into three basic groups based on the type of transduction element: optical biosensors, mechanical biosensors, and electrochemical sensors [22]. An example of different components of biosensors used in food analysis is shown in Figure 1. Many compounds, such as bacterial antigens, toxins, microbial contaminated by-products, or spoilage precursors, could be easily detected using biosensors for the rapid analysis of food deterioration and food quality [101].

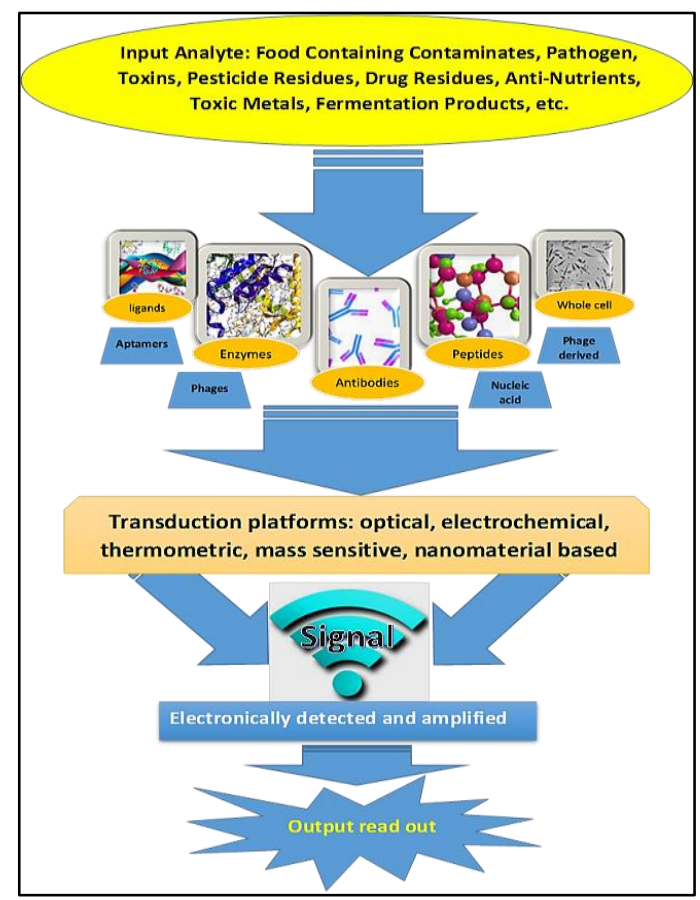

Figure 1. Diagram showing the different components of a biosensor used in food analysis.

\subsection{Types of Biosensors}

Biosensors are categorized into various groups depending on their working principles (Figure 2). Examples of biosensors include electrochemical, mechanical, biological, acoustic sensors, surface plasmon resonance (SPR), and optical biosensors. Three of the most important biosensors are discussed below. 


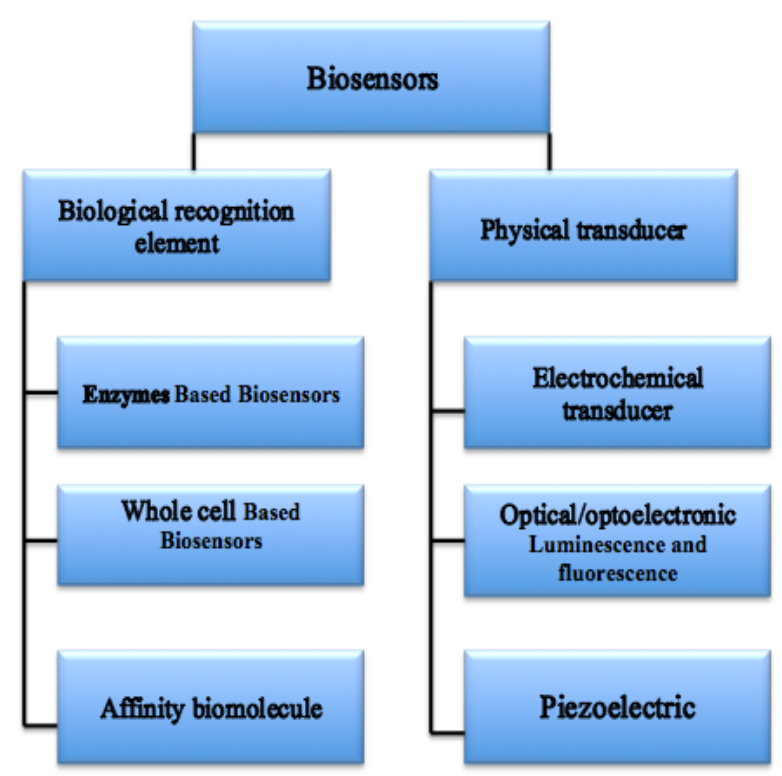

Figure 2. Schematic representation of various combinations of physical and biological elements of biosensors.

\subsubsection{Optical Biosensors}

Optical biosensor methods characterized by high sensitivity, simple handling, and rapid detection have been used extensively to identify very large numbers of bacteria [102]. Optical biosensors enable visualization of microbial activities in food with the naked eye. The alteration in the transduction surface due to cell connection by means of direct binding or ligand identification assists in active analyte detection. Ivnitski et al. [103] demonstrated that optical biosensors may distinguish microbes in food through either in situ detection in the refractive index or by means of the thickness that develops as bacterial cells attach to receptors on the transducer surface [103]. The optical biological sensor contains a biodegradable polymer by analytical enzymes secreted by microorganisms during the deterioration of the natural product. As the number of bacteria increases, there is increased secretion of enzymes that cause food degradation, which will be visible with the degradation of the polymer [104]. Colorimetric, fluorescence, chemiluminescence, and surface plasmon resonance (SPR) are the principal optical techniques employed [105]. Newly created biosensors for the identification of microbial contamination in food items are shown in Table 3.

Alamer et al. [105] developed an immunoassay with sandwich to diagnose pathogenic bacteria in poultry such as Salmonella Typhimurium, Staphylococcus aureus, Salmonella enteritidis, and Campylobacter jejuni. Immobilized lactoferrin on a cotton swab was employed to pick up the bacterial contamination on the surface of the chicken, accompanied by a sandwich immunoassay formulated with a different antibody coupled with colored nano-beads. The form and concentration of the present microorganism defined the color and strength of the cotton swab [105]. Several plant pathogens including the cucumber mosaic virus [106], Pantoea stewartii [107], plum pox virus [108], Prunus necrotic ringspot virus [109], citrus tristeza virus [110], and potato virus [111] have already been detected using various optical biosensors. SPR biosensors have been used to successfully identify and detect cowpea mosaic virus, tobacco mosaic virus, lettuce mosaic virus, Fusarium culmorum, Phytophthora infestans, and Puccinia striiformis [112].

\subsubsection{Electrochemical Biosensors}

Electrochemical biosensing techniques are among the most employed platforms for detection of foodborne pathogens [113]. Electrochemical biosensors have been reported to be successful techniques for bacterial detection due to their low cost, accuracy, miniaturization capacity and ability to detect changes directly based on the interaction between the sensor and sample. However, the time required 
to detect food contamination using electrochemical biosensors has significantly decreased with the advancement of new methods, some of which require as little as $10 \mathrm{~min}$ [19]. Electrochemical biosensors are categorized according to the various electrical signals produced by the existence of targets into impedimetric, potentiometric, amperometric, electrochemiluminescent, voltammetric, and conductometric methods [114].

During the last decade, exponential development in electrochemical biosensors has been observed for analysis of food and beverages and to identify genetically modified organisms (GMOs) in food [19]. Chen and colleagues recently established and developed polyaniline- carbon nanotubes (CNTs) as a redox nanoprobe connected to a signal probe to enhance the electrochemical signal for Mycobacterium tuberculosis detection [115]. A single-walled carbon nanotube (SWCNT) biosensor was successfully immobilized with a polyclonal antibody to detect Yersinia enterocolitica in Kimchi solutions with a low detection of $4 \log$ CFU/mL [116]. The disposable potentiometric paper-based biosensor was designed to detect of Salmonella Typhimurium. In the first step, the combination from ethylenedioxythiophene:polystyrene sulfonate was coated on filter paper. Next, antibodies to the target bacteria were covalently attached to filter paper. A linear range of $4.07 \log \mathrm{CFU} / \mathrm{mL}$ was recorded, with a detection limit of $0.698 \log \mathrm{CFU} / \mathrm{mL}$. Less than $5 \mathrm{~min}$ was sufficient to perform the analysis and obtain the results [117]. Similarly, Silva and coworkers developed another approach for Salmonella Typhimurium detection in apple juice using a potentiometric biosensor conjugating on a gold nanoparticle polymer inclusion membrane, and a detection limit of 6 cells/mL was achieved [118].

\subsubsection{Mechanical Biosensors}

Mechanical biosensors can measure a mass sensitive sensor surface deflection because the target analytes will be bonded on the functionalized surface [119]. Mechanical biosensors are typically classified into four broad groups according to the sensor-analyte chemical interactions: affinity-based assays, fingerprint assays, separation-based assays, and spectrometric assays [120]. Quartz crystal microbalance (QCM) is a mechanical biosensor that is widely used due to its capacity to track shifts in mass in sub-nanogram amounts. The change in mass using QCM biosensors is recognized by the resonant frequency of quartz crystal, and this technique is commonly used with extreme sensitivity for quantification of the whole cell of microorganisms [121]. Bayramoglu et al. [122] designed A QCM-aptasensor to isolate and rapid detect Brucella melitensis in milk and milk products. The aptamer was immobilized on magnetic nanoparticles and the QCM chip for the quantitative detection of B. melitensis with high specificity. The QCM biosensor detection limit for determination of B. melitensis was $3 \log \mathrm{CFU} / \mathrm{mL}$ [122].

Lectins were employed and immobilized as a recognition element on the surface of the QCM chip to detect the foodborne pathogen Campylobacter jejuni. The limit of detection was $3 \log$ CFU/mL. A modified strategy was utilized to improve the sensitivity of the assay by Masdor et al. [123] who detected E. Campylobacter jejuni based on the inclusion of antibody conjugated gold nanoparticles. The limit of detection was enhanced and found to be $2.17 \log$ CFU/mL because the gold nanoparticles exhibited mass amplification effects. Several other studies were successfully employed to develop a novel sensor based on a quartz crystal microbalance with dissipation to detect the most widely spread mycotoxins in red wine called ochratoxin A. The method described here was fast, sensitive, and cost effective, and the analysis time was less than one hour. A limit of detection of $0.16 \mathrm{ng} / \mathrm{ml} \mathrm{was}$ attained with an excellent linear range between 0.2 and $40 \mathrm{ng} / \mathrm{ml}$ [124]. The most advanced mechanical biosensors for the identification of microbial contamination in food items are shown in Table 3. 
Table 3. Newly Created Biosensors for the Identification of Various Contaminants in Food Items.

\begin{tabular}{|c|c|c|c|c|c|}
\hline Type of Sensor & Contaminant & Food Items & Detection Limit & $\begin{array}{l}\text { Consuming } \\
\text { Times }\end{array}$ & Reference \\
\hline \multicolumn{6}{|c|}{ Optical Biosensor } \\
\hline Chemiluminescence & $\begin{array}{c}\text { Listeria } \\
\text { monocytogenes }\end{array}$ & Milk & $1.1 \log \mathrm{CFU} / \mathrm{mL}$ & $40 \mathrm{~min}$ & Shang et al. [125] \\
\hline Colorimetric & $\begin{array}{c}\text { Cronobacter } \\
\text { sakazakii }\end{array}$ & $\begin{array}{l}\text { Powdered } \\
\text { Infant }\end{array}$ & $3.85 \log \mathrm{CFU} / \mathrm{mL}$ & $30 \mathrm{~min}$ & $\begin{array}{l}\text { Kim et al. [126] } \\
\text { Shukla et al. [127] }\end{array}$ \\
\hline $\begin{array}{c}\text { localized Surface Plasmon } \\
\text { Resonance (LSPR) }\end{array}$ & $\begin{array}{l}\text { Salmonella } \\
\text { typhimurium }\end{array}$ & Pork Meat & $4 \log \mathrm{CFU} / \mathrm{mL}$ & $30-35 \mathrm{~min}$ & Oh et al. [128] \\
\hline Interferometric & Escherichia coli & Buffer & $0.34 \log \mathrm{CFU} / \mathrm{mL}$ & $2 \mathrm{~h}$ & $\begin{array}{l}\text { Zaraee et al. [129] } \\
\text { Janik [130] }\end{array}$ \\
\hline $\begin{array}{l}\text { Surface Plasmon } \\
\text { Resonance (SPR) }\end{array}$ & Pseudomonas & Water & $7.09 \log \mathrm{CFU} / \mathrm{mL}$ & $25 \mathrm{~min}$ & $\begin{array}{l}\text { Mudgal et al. [131] } \\
\text { Zhang et al. [132] }\end{array}$ \\
\hline \multicolumn{6}{|c|}{ Mechanical Biosensor } \\
\hline $\begin{array}{l}\text { Multi-Channel Series } \\
\text { Piezoelectric Guartz } \\
\text { Crystal (MSPQC) }\end{array}$ & $\begin{array}{l}\text { Mycobacterium } \\
\text { tuberculosis }\end{array}$ & Buffer & $1 \log C F U / m L$ & 1 day & $\begin{array}{l}\text { Ren et al. [133] } \\
\text { He et al. [134] }\end{array}$ \\
\hline $\begin{array}{c}\text { Quartz Crystal } \\
\text { Microbalance (QCM) }\end{array}$ & Salmonella & Milk & $2 \log C F U / m L$ & $10 \mathrm{~min}$ & $\begin{array}{l}\text { Ozalp et al. [135] } \\
\text { Farka et al. [136] }\end{array}$ \\
\hline QCM & $\begin{array}{l}\text { Campylobacter } \\
\text { jejuni }\end{array}$ & Poultry & $1.30 \log \mathrm{CFU} / \mathrm{mL}$ & $30 \mathrm{~min}$ & $\begin{array}{l}\text { Wang et al. [137] } \\
\text { Masdor et al. [138] }\end{array}$ \\
\hline QCM & $\begin{array}{c}\text { Staphylococcus } \\
\text { aureus }\end{array}$ & Buffer & $7.41 \log C F U / m L$ & 1 day & $\begin{array}{l}\text { Pohanka [139] } \\
\text { Noi et al. [140] }\end{array}$ \\
\hline \multicolumn{6}{|c|}{ Electrochemical } \\
\hline Potentiometric & $\begin{array}{l}\text { Staphylococcus } \\
\text { aureus }\end{array}$ & Pig skin & $2.90 \log \mathrm{CFU} / \mathrm{mL}$ & $2 \mathrm{~min}$ & $\begin{array}{c}\text { Zelada-Guillén et al. [141] } \\
\text { Arora et al. [142] }\end{array}$ \\
\hline Impedimetric & $\begin{array}{l}\text { Salmonella } \\
\text { Typhimurium }\end{array}$ & Apple Juice & $0.47 \log \mathrm{CFU} / \mathrm{mL}$ & $45 \mathrm{~min}$ & $\begin{array}{l}\text { Sheikhzadeh et al. [143] } \\
\text { Bagheryan et al. [144] }\end{array}$ \\
\hline Amperometric & $\begin{array}{l}\text { Streptococcus } \\
\text { agalactiae }\end{array}$ & Fish & $1-7 \log \mathrm{CFU} / \mathrm{mL}$ & $90 \mathrm{~min}$ & $\begin{array}{l}\text { Vásquez et al. [145] } \\
\text { Arachchillaya [146] }\end{array}$ \\
\hline \multicolumn{6}{|c|}{ Electrochemical Chemiluminescence (ELC) Biosensors } \\
\hline $\begin{array}{l}\text { Aptamer-Based ECL } \\
\text { Sensors }\end{array}$ & Escherichia coli & $\begin{array}{l}\text { Luria-Bertani } \\
\text { Broth }\end{array}$ & $0.17 \mathrm{CFU} / \mathrm{mL}$ & $40 \mathrm{~min}$ & Hao et al. [147] \\
\hline ECL Immunosensor & $\begin{array}{c}\text { Vibrio } \\
\text { parahaemolyticus }\end{array}$ & Seafood & $0.69 \log \mathrm{CFU} / \mathrm{mL}$ & $1 \mathrm{~h}$ & Sha et al. [148] \\
\hline $\begin{array}{l}\text { Paper-Based Bipolar } \\
\text { electrode ECL }\end{array}$ & $\begin{array}{c}\text { Listeria } \\
\text { monocytogenes }\end{array}$ & Buffer & 10 copies $/ \mu \mathrm{L}$ & $10 \mathrm{~s}$ & Liu and Zhou [149] \\
\hline \multicolumn{6}{|c|}{ Photoelectrochemical Biosensors } \\
\hline $\begin{array}{c}\text { label-Free } \\
\text { Photoelectrochemical } \\
\text { Aptasensor }\end{array}$ & Bisphenol & Milk & $0.5 \mathrm{nM}$ & $90 \mathrm{~s}$ & Qiao et al. [150] \\
\hline $\begin{array}{c}\text { Tungsten Disulfide (WS2) } \\
\text { Nanosheet-Based } \\
\text { Photoelectrochemical }\end{array}$ & Chloramphenicol & Milk Powder & $3.6 \mathrm{pM}$ & $105 \mathrm{~min}$ & Zhou et al. [151] \\
\hline $\begin{array}{c}\text { Visible-Light } \\
\text { Photoelectrochemical } \\
\text { Aptasensing }\end{array}$ & Sulfadimethoxine & Milk & $0.55 \mathrm{nM}$ & $50 \mathrm{~s}$ & Okoth et al. [152] \\
\hline
\end{tabular}

\section{Bioluminescence Methods for Detection of Food Contamination}

The overall number of microbes is normally calculated using colony plate counts, dilution methods, methods of contact plate and swab, or techniques of membrane filtering. These methods produce repeatable findings that reflect the microbiological contamination. However, the long incubation time of the sample (up to $72 \mathrm{~h}$ for bacteria; up to 5 days for fungi) does not allow for rapid correction within one technical process, so for this purpose, tests to estimate the amount of bacteria need to be added quickly [153]. Consequently, Sharpe et al. [154] proposed utilizing the ATP test dependent on bioluminescence. This approach is becoming increasingly common in HACCP program in situ hygiene monitoring. Its principal benefit is the identification of microbial and chemical pollutants within a few minutes. 
Recent developments in bio-analytical instruments have allowed for using the capacity of certain enzymes to release photons as a by-product of the enzymes' reactions. This effect is known as "bioluminescence", which can be used to identify the cells' activity. This technique provides results in a short time and is among the latest technologies for rapid microbiological results [155]. Bioluminescence plays an important role in real-time process monitoring due to the emission of bright light by living microorganisms. Some study results also demonstrated that metal ions, heavy metals, phosphorus, naphthalene, genotoxicants and chlorophenols were detected by employing bioluminescence-based biosensors [156]. The bioluminescent organisms in nature are broadly distributed and include a wide remarkably different of species. Among the organisms that emit light are bacteria, dinoflagellates, fungi, fish, insects, shrimp, and squid. The enzyme luciferase is responsible for catalyzing the bioluminescence reactions that occur in these organisms, and in certain instances the substrates are referred to as luciferins. Bioluminescence is very effective when used for fast spot tracking because tests are obtained in less than 15 minutes [157]. This procedure has been used on several food items including fresh and pasteurized dairy products [158], meat and poultry products [159], beer [160], and fruit products [161].

Sanitizing programs and hazard analysis and critical control point (HACCP) programs can be achieved in the food processing industry by using the common bioluminescence method of adenosine triphosphate (ATP). Bioluminescence assays and the identification of bacterial adenosine triphosphate (ATP) are strong predictors of the occurrence of food contamination in meat, poultry and dairy products and the cross-contamination of surfaces [162]. All living organisms use ATP to store energy. ATP acts as a chemical energy storage unit for free energy that is emitted through catabolism and thereafter used for anabolic processes [163]. The amount of ATP specifically reflects the presence of metabolic cells and can be used to count viable living cells in samples. This is because there is a linear association between the total number of available ATP molecules and the total number of colony-forming units, especially in bacteria and yeast [164].

The relationship between microbial biomass and intercellular ATP can be used to quantify the total number of microorganisms in food items. Recent studies have shown that the amount of ATP present in a cell differs based on the species and growth states of microorganisms. For instance, the extracellular ATP present in Acinetobacter junii and Pseudomonas aeruginosa at an incubation time of $6 \mathrm{~h}$ was $255.2 \pm 56.8 \mathrm{nM} / \mathrm{OD}$ and $25.5 \pm 1.1 \mathrm{nM} / \mathrm{OD}$, respectively [165]. Xu et al. [88] developed the traditional ATP fluorescence detection system by using a rapid detection system based on a nanoprobe and graphite electrode coupled with ATP bioluminescence technology for Escherichia coli detection in food. With this new approach, the researchers were not only able to use the probe to capture and enrich Escherichia coli via an antibody-antigen reaction, they were also able to enrich ATP using an electric field generated by the graphene transparent electrode (GTE) in order to improve the accuracy of the system. This method resulted in the successful generation of a linear correlation coefficient of up to 0.972 compared to other traditional methods and satisfied the design criteria. The analysis was obtained within $20 \mathrm{~min}$. The system was able to detect the total bacteria count in the range of 2-6 $\log \mathrm{CFU} / \mathrm{mL}$, and its precision has a CV of $4.2 \%$, indicating good reliability and repeatability [88].

Moreover, Fan and colleagues confirmed the possibility of developing a bioluminescence-based ATP assay using antibacterial peptide-coated magnetic spheres to distinguish Gram-positive $\mathrm{G}^{+}$bacteria from Gram-negative $\mathrm{G}^{-}$bacteria. The authors obviously found the conventional bioluminescence-based ATP cannot distinguish $\mathrm{G}^{+}$bacteria from $\mathrm{G}^{-}$ones since ATP can be released from both bacterial cells. The results exhibited a linear range for $\mathrm{G}^{+}$bacteria between 3.36 and $7.07 \log \mathrm{CFU} / \mathrm{mL}$, and the limit of detection was $2.34 \log \mathrm{CFU} / \mathrm{mL}$ within $33 \mathrm{~min}[166]$.

\section{Principle of Bioluminescence Based-ATP Determination}

Adenosine triphosphate is the main activated energy carrier of all living cells in nature, including bacteria, mold, yeast, and algae [167]. ATP levels can also be used as a criterion for microbial activity measurement. ATP bioluminescence is based on a biochemical reaction catalyzed by the enzyme [168]. 
The reaction is catalyzed by the luciferase enzyme conversion of luciferin to oxyluciferin in the presence of oxygen $\left(\mathrm{O}_{2}\right)$ and magnesium cation $\left(\mathrm{Mg}^{++}\right)$, and ATP adenosine triphosphate is converted to adenosine monophosphate (AMP) with the emission of light [169]. The intensity of light in the luminescence reaction is expressed in relative light units (RLU). The reaction between ATP and luciferin and luciferase complex is described according to the following equation:

$$
\text { Luciferin }+\mathrm{ATP}+\mathrm{O}_{2} \stackrel{\text { luciferase, } \mathrm{Mg}+2}{\longrightarrow} \text { Oxyluciferin }+\mathrm{AMP}+\text { prodcuts }+ \text { light }
$$

This light output from the breakdown of cellular ATP by the bioluminescence reaction can be measured using sensitive photons of light meters in an instrument called a luminometer. The greater the amount of ATP will present, the higher amount of light produced by the APP assay test; consequently, the greater the RLU level produced. ATP bioluminescence has often been used for the investigation of microbial contamination of food contact surfaces and for measuring the efficiency of cleaning procedures. It is a simple and rapid method that provides results within minutes compared to conventional methods, which typically take 24-48 h. Libudzisz and Kowal and [170] stated that on the bacterial cell possesses approximately 1 ATP femtogram. Based on the species, physiological status or metabolic function of microorganisms, the concentration will vary from 0.1 to $5.5 \mathrm{fg} / \mathrm{cell}$. Luo et al. [171] claimed that the average concentration of ATP in a cell is approximately $0.47 \mathrm{Cell} \mathrm{fg}$. To determine the number of microbes in each sample, it is presumed that $1 \mathrm{pg}$ of ATP is equal to 1000 bacterial cells. Table 4 below shows the content of ATP (fg/cell) in some bacterial, mold, and yeast cells.

Table 4. The Content of ATP (fg/cell) in Some Bacterial, mold and Yeast Cells.

\begin{tabular}{ccc}
\hline Microorganisms & ATP (fg/Cell) & References \\
\hline Campylobacter jejuni & 1.7 & Ng et al. [172] \\
\hline Yeast & 100 & Miller and Galston [173] \\
\hline Lactobacillus sp. & $2.0-2.2$ & Libudzisz and Kowal [170] \\
\hline Pseudomonas fluorescens & 0.6 & Pistelok et al. [174] \\
\hline Escherichia coli & 1 & Libudzisz and Kowal [170] \\
\hline Bacteria Mixture & 1 & Miller and Galston [173] \\
\hline Lactobacillus acidophilus & 0.33 & Nelson [175] \\
\hline Campylobacter coli & 2.1 & Ng et al. [172]
\end{tabular}

\section{Applications of Bioluminescence Based ATP in the Food Industry}

\subsection{Hygiene Monitor}

The efficacy of ATP-based bioluminescent assays is enhanced due to their ability to provide rapid results that indicate the existence or absence of certain biological contaminants in real time [176]. ATP bioluminesce assays are widely used in the food industry for estimating the cross-contamination of surfaces and products through swabbing. This type of application enables results within 5 min that are just as accurate as those obtained using traditional techniques. The levels of overall surface contamination can be indicated successfully because ATP from all microbial sources will be detected [177]. The time of bacterial viability on certain kitchen surfaces ranges between four and $24 \mathrm{~h}$. Therefore, during food preparation it is necessary to design appropriate hygienic protocols such as proper washing and disinfection to control and avoid microbial risks. The ATP test thus helps to quickly verify that surfaces are clean and properly disinfected. In addition, this method does not pose a threat to humans [178]. However, because raw materials of plant or animal origin increase ATPs, the test results can be overstated. About cleanliness and hygiene, it is not known yet whether microorganisms or traces of biological content are found throughout the work and the production equipment by 
measuring only the ATP [179]. In this case, the values are usually dependent on the relative light units (RLU) rather than the concentration of ATP collected. The findings are correlated with the previously defined baseline levels for the industry and the individual measurement points. Low RLU rates would mean that the measurement point is safe and clear of chemical and microbiological contaminants, while high RLU levels would be indicative of points of contamination [179]. In a study conducted by Rodrigues et al. [180], the relationship between the values of ATP-bioluminescence and the extent of microbial contamination was estimated according to traditional methods in order to evaluate the cleanliness of the cutting surfaces in the poultry slaughterhouse [180]. Their findings confirmed that that there was a linear relationship between the microbial content using conventional methods and the bioluminescent ATP approach. Using the bioluminescent ATP detection system, extremely low contamination rates can be identified in seconds, enabling a rapid assessment of the surface hygiene [180].

Despite rapid hygiene monitoring using ATP tests, recent studies by Bakke and Suzuki [181] who reported that ATP could be hydrolyzed by heat treatment, acidic factors or alkaline conditions to ADP and AMP. Consequently, the values of collected RLU will not be accurate. Bakke and Suzuki [181] have developed a novel hygiene monitoring based on the detection of total adenylate (A3) in a wide variety of foods such as fermented foods, dairy, vegetables, meat, nuts, seafood, and fruits. After thorough washing with detergent and rinsing the stainless steel, the amount of collected RLU of A3 was 200. In contrast, less than 200 RLU was seen on a traditional ATP system. In conclusion, the A3 assay seems to be a successful approach and more sensitive for detecting adenylates from food residues that are not identified by traditional ATP assays [181].

\subsection{Milk and Dairy Products}

The shelf life of milk depends on its initial microbial load, the form and distribution of microbes, and how well such microbes grow under different storage conditions. Conventional qualitative and quantitative methods were applied in microbiological analysis of food to detect microbial contamination using a selective media, non-selective media and biochemical screening [182]. These approaches are time-consuming and require additional confirmation and interpretation by qualified technicians, which can take several days. Therefore, an alternate, fast, efficient, and lower cost method for real-time identification of milk spoilage is warranted [183]. Recently, the bioluminescence-based ATP technique has been developed to monitor the presence of microorganisms and can easily be applied to determine both somatic cell counts (SCC) and microbial counts for controlling raw milk production quality $[178,184]$. After treatment with a non-ionic detergent, an indication of the somatic cell concentration in milk can be obtained from the ATP concentration level. This result can be considered as an indicator for infection with mastitis [178]. Indeed, Moore et al. [185] reported that ATP bioluminescence procedures were performed in 5-10 min to detect as few as $4 \log \mathrm{CFU} / \mathrm{mL}$ of milk bacteria which undoubtedly resulted in faster and better-informed decisions regarding the status of incoming milk tankers the milk processing industries.

Other studies have examined the use of the bioluminescence -based ATP technique compared to total bacterial count (TBC) cultivation for rapid microbial identification to monitor ultra-high temperature (UHT) milk quality [186]. ATP bioluminescence was suitable for detecting very low concentrations of microbial content compared to results for conventional total bacterial counts, and the analysis time was only $20 \mathrm{~min}$. Similarly, Lomakina and others used a bioluminescence ATP assay to ascertain the quality of milk within 20 min with a detection limit of approximately $1.11 \log \mathrm{CFU} / \mathrm{mL}[168]$.

\subsection{Meat and Meat Products}

Meat and meat products can be used effectively as rich media for growing several microflora (bacteria, yeasts, and molds), some of which are pathogens [187]. The ATP bioluminescence method was used to monitor the microbial content of meat. The study reported that there was a significant 
correlation between the content of ATP and total bacteria counts of vacuum-packed cooked cured meat products, and a detection limit of 5-6 log CFU/g was sufficient for screening purposes [188]. Similarly, Siragusa and colleagues established a quick ATP assay to quantify total bacteria counts in beef and pork carcasses in commercial food industries and to compare findings with the standard method of viable plate counts using correlation analysis [189]. The results of this research showed that the correlation coefficient between the conventional microbiological assay and the ATP method was 0.91 for beef and 0.93 for pork carcass samples. The ATP test applied linearly to microbial contamination rates $>\log 2.0$ aerobic $\mathrm{CFU} / \mathrm{cm}^{2}$ in carcasses of beef and $>\log 3.2$ aerobic $\mathrm{CFU} / \mathrm{cm}^{2}$ in carcasses of pork. The ATP test including sampling took approximately 5 min [190].

However, one concern with this approach is the presence of ATP in meat and in all living cells. Therefore, ATP must be destroyed before an ATP bioluminescence method can be performed to measure only the microbial ATP produced [190,191]. Hence, Cheng et al. [190] conducted an experiment to combine an ATP bioluminescence assay with functional magnetic nanoparticles (FMNPs) for rapid isolation and detection of Escherichia coli from artificially contaminated ground beef. To release the target bacterial ATP in the presence of luciferin-luciferase mechanism, immune particles were used to precisely capture and separate the bacteria to generate the luminescence signal. E. coli bacteria can be calculated with a detection limit of $1.30 \log \mathrm{CFU} / \mathrm{mL}$ in the range of $1.30-6.30 \log \mathrm{CFU} / \mathrm{mL}$. The whole process used to identify E. coli took approximately $1 \mathrm{~h}$. The range of identification and assay time obtained in this study has been shown to be superior to that of other techniques [190].

\subsection{Fish and Fish Products}

For more than 50 years, ATP and associated compounds have been used for the quality evaluation of fish and shellfish [192]. Bioluminescence is the production and release of light by a living entity and exists commonly in aquatic vertebrates and invertebrates. Shim et al. [193] measured the ATP content in the muscle of olive flounder (Paralichthys olivaceus) by calculating the intensity of light released using luciferase provided by American fireflies. The findings of bioluminescence were nearly equal to high-performance liquid chromatography (HPLC). Indeed, the results of the study showed a high correlation of $\mathrm{r}^{2}=0.98$ between luminometer-measured RLU and HPLC-based ATP content. Tanaka et al. [194] have established a bioluminescence system for the identification of AMP in the Atlantic bonito (Sarda sarda). Polyphosphate (polyP)-AMP phosphotransferase (PPT) and adenylate kinase (ADK) were utilized from the Acinetobacter johnsonii strain conjugated with firefly luciferase. With this approach, the researchers were able to identify high-sensitivity AMP in food residues [194]. Regarding the evaluation of different microbiological methods, Gram [195] found that the correlation between bacterial ATP levels and plate counts was 0.97-0.99 for four fish species. During storage trials, the ratio of bacterial ATP to total count bacteria remained constant and did not vary significantly among fish species [195]. As the amount of ATP per cell varies based on nutritional conditions, stress, etc., it is advised that a standard curve for each specific product be generated [196].

Other experiments conducted by Miettinen et al. [197] reported the presence of Listeria in 28 fish processing factories and the extent of surface contamination utilizing specific approaches such as total aerobic heterotrophic and enterobacteria, yeast and mold tests and ATP levels. ATP tests and the total bacteria contact agar slide methods were negatively associated $(r=0.21)$. However, for both methods, 68 percent of the samples were rated as decent to fair or unacceptable. The microbiological limit of 1 RLU using an ATP assay was exceeded in $43.3 \%$ of the samples. The results of this study confirmed that the ATP system recognized $18.1 \%$ of the samples that were considered contaminated per the results of the contact agar slide process, and $13.6 \%$ of the samples allowed by the contact agar slide system were rejected by the ATP process [197].

\section{Advantages and Disadvantages of ATP Bioluminescence}

ATP bioluminescence provides a better image of the reaction to the contaminant by presenting physiologically relevant data. Bioluminescence is fast and simple to calculate, resulting in the in-situ 
detection of a wide range of microorganisms. The bioluminescent sensors of whole cells have benefits over conventional approaches by being faster, more cost effective, easy to carry out and less labor-intensive [198]. While not an alternative to traditional approaches, an ATP-bioluminescence-assay can also be a valuable tool for determining the efficacy of environmental cleanliness procedures even with very low microbial counts [199]. Moreover, bioluminescent techniques often possess several benefits compared to fluorometric techniques mainly because no wavelength of excitation is required for the representation of light. In addition, unlike the fluorescent labeling of bacterial species, there is a total energy reliance on the emission of bioluminescents, which enables the capability to distinguish between living and dead cells. Consequently, bioluminescence is a highly valuable instrument for regulating in situ microbial deterioration and is thus a desirable tool for hygiene efficacy [200].

Luminescent approaches often pose some general disadvantages. The most significant disadvantage is the quenching of released light, which negatively influences measurements. The sum of light determined photometrically may be greatly decreased by molecules from the biological samples. However, the biological samples produce certain luminescent non-microbial substances that increase the intensity of the measured light. Bacterial bioluminescent assays are thus capable of being a liability in the food microbiology industry. For example, the results of bacterial bioluminescent assays can be false negatives or false positives by using phage or plasmid host ranges that are either too specific or too extensive [177]. Another disadvantage of bacterial bioluminescent assays is their unreliability about efficiently identifying gram-negative bacteria due to the incomplete lysis of the cells [201].

\section{Conclusions and Future Directions}

Developing biosensors with the necessary properties for reliable and effective use in routine applications is challenging. Despite the great effort spent on the development of various types of biosensors over the past few years, only a few for bacterial detection are commercially available or are approaching commercialization. Requirements for ideal sensors include the specificity to distinguish the target bacteria in a complex food product, sensitivity to detect bacteria directly, and the ability to provide real-time results within a reasonable time. Detection of pathogen or toxic chemicals in food matrix is not a simple and rapid approach. Indeed, it requires additional preparation steps before detection. This includes sample preparation and harvesting the target microbial cells or chemical. The development of any rapid biosensors for detection of pathogens also relies on the type of food products and the nutrients present in these products, such as fat, proteins, and fibers. Hence, there might be a need to develop a specific sensor for each food product or specific analytical tools and sampling methods.

This review highlights potentially reliable biosensor methods to expand research in this area and to address the need for the development of more economical and cost-effective methods. In addition, there is a need to develop a portable bioluminescence-based ATP unit that can be utilized on farms to detect pathogens on the surface of fresh produce. Moreover, such biosensors should provide reliable results in addition to being easy and simple to use without the need for consumer training.

Funding: This research received no external funding.

Acknowledgments: The authors are thankful to the Department of Food Science, College of Agriculture, University of Basrah for providing all assistance to complete this review.

Conflicts of Interest: The authors declare no conflict of interest.

\section{References}

1. Randhawa, M.A.; Asghar, A.; Nadeem, M.; Ahmad, N. Food Safety: Benefits of Contamination Control on Consumers' Health. In Food Safety and Preservation; Academic Press: Cambridge, MA, USA, 2018; pp. 13-38.

2. Chatterjee, A.; Abraham, J. Microbial contamination, prevention, and early detection in food industry. In Microbial Contamination and Food Degradation; Academic Press: Cambridge, MA, USA, 2018; pp. 21-47.

3. Forsythe, S.J. The Microbiology of Safe Food; John Wiley \& Sons: Hoboken, NJ, USA, 2020. 
4. Barbosa, J.; Albano, H.; Silva, C.P.; Teixeira, P. Microbiological contamination of reusable plastic bags for food transportation. Food Control 2019, 99, 158-163. [CrossRef]

5. Gursoy, D. Foodborne illnesses: An overview of hospitality operations liability. J. Hosp. 2019, 1, 41-49.

6. Mead, P.S.; Slutsker, L.; Dietz, V.; McCaig, L.F.; Bresee, J.S.; Shapiro, C.; Tauxe, R.V. Food-related illness and death in the United States. Emerg. Infect. Dis. 1999, 5, 607. [CrossRef] [PubMed]

7. Nakao, J.H.; Talkington, D.; Bopp, C.A.; Besser, J.; Sanchez, M.L.; Guarisco, J.; Xavier, K. Unusually high illness severity and short incubation periods in two foodborne outbreaks of Salmonella Heidelberg infections with potential coincident Staphylococcus aureus intoxication. Epidemiol. Infect. 2018, 146, 19-27. [CrossRef]

8. Sankarankutty, K.M. Biosensors and their applications for ensuring food safety. Glob. J Pathol Microbiol 2014, 2, 15-21. [CrossRef]

9. Rajapaksha, P.; Elbourne, A.; Gangadoo, S.; Brown, R.; Cozzolino, D.; Chapman, J. A review of methods for the detection of pathogenic microorganisms. Analyst 2019, 144, 396-411. [CrossRef]

10. Wang, W.; Wang, Y.; Lin, L.; Song, Y.; Yang, C.J. A tridecaptin-based fluorescent probe for differential staining of Gram-negative bacteria. Anal. Bioanal. Chem. 2019, 411, 4017-4023. [CrossRef]

11. Chae, W.; Kim, P.; Hwang, B.J.; Seong, B.L. Universal monoclonal antibody-based influenza hemagglutinin quantitative enzyme-linked immunosorbent assay. Vaccine 2019, 37, 1457-1466. [CrossRef]

12. Liu, Y.; Cao, Y.; Wang, T.; Dong, Q.; Li, J.; Niu, C. Detection of 12 common food-borne bacterial pathogens by TaqMan real-time PCR using a single set of reaction conditions. Front. Microbiol. 2019, 10. [CrossRef]

13. Etheridge, J.R.; Randolph, M.; Humphrey, C. Real-Time Estimates of Escherichia coli Concentrations Using Ultraviolet-Visible Spectrometers. J. Environ. Qual. 2019, 48, 531-536. [CrossRef]

14. Batani, G.; Bayer, K.; Böge, J.; Hentschel, U.; Thomas, T. Fluorescence in situ hybridization (FISH) and cell sorting of living bacteria. Sci. Rep. 2019, 9, 1-13. [CrossRef] [PubMed]

15. Duffy, G.F.; Moore, E.J. Electrochemical immunosensors for food analysis: A review of recent developments. Anal. Lett. 2017, 50, 1-32. [CrossRef]

16. Weng, X.; Neethirajan, S. Ensuring food safety: Quality monitoring using microfluidics. Trends Food Sci. Technol. 2017, 65, 10-22. [CrossRef]

17. Nemati, M.; Hamidi, A.; Dizaj, S.M.; Javaherzadeh, V.; Lotfipour, F. An overview on novel microbial determination methods in pharmaceutical and food quality control. Adv. Pharm. Bull. 2016, 6, 301. [CrossRef]

18. Poghossian, A.; Geissler, H.; Schöning, M.J. Rapid methods and sensors for milk quality monitoring and spoilage detection. Biosens. Bioelectron. 2019. [CrossRef]

19. Mishra, G.K.; Barfidokht, A.; Tehrani, F.; Mishra, R.K. Food safety analysis using electrochemical biosensors. Foods 2018, 7, 141. [CrossRef]

20. Patel, P.D. Biosensors for measurement of analytes implicated in food safety: A review. TrAC Trends Anal. Chem. 2002, 21, 96-115. [CrossRef]

21. Chollet, R.; Ribault, S. Use of ATP bioluminescence for rapid detection and enumeration of contaminants: The milliflex rapid microbiology detection and enumeration system. In Bioluminescence-Recent Advances in Oceanic Measurements and Laboratory Applications; IntechOpen: London, UK, 2012.

22. Jayan, H.; Pu, H.; Sun, D.W. Recent development in rapid detection techniques for microorganism activities in food matrices using bio-recognition: A review. Trends Food Sci.Technol. 2019, 95, 233-246. [CrossRef]

23. Zhang, Z.; Wang, C.; Zhang, L.; Meng, Q.; Zhang, Y.; Sun, F.; Xu, Y. Fast detection of Escherichia coli in food using nanoprobe and ATP bioluminescence technology. Anal. Methods 2017, 9, 5378-5387. [CrossRef]

24. Faour-Klingbeil, D.; CD Todd, E. Prevention and Control of Foodborne Diseases in Middle-East North African Countries: Review of national control systems. Int. J. Environ. Res. Public Health 2020, 17, 70. [CrossRef]

25. Scallan, E.; Griffin, P.M.; Angulo, F.J.; Tauxe, R.V.; Hoekstra, R.M. Foodborne illness acquired in the United States unspecified agents. Emerg. Infect. Dis. 2011, 17, 16. [CrossRef] [PubMed]

26. Tauxe, R.V. Emerging foodborne pathogens. Int. J. Food Microbiol. 2002, 78, 31-41. [CrossRef]

27. Cacciò, S.M.; Chalmers, R.M.; Dorny, P.; Robertson, L.J. Foodborne parasites: Outbreaks and outbreak investigations. A meeting report from the European network for foodborne parasites (Euro-FBP). Food Waterborne Parasitol. 2018, 10, 1-5.

28. Wu, Y.N.; Liu, X.M.; Chen, Q.; Liu, H.; Dai, Y.; Zhou, Y.J.; Chen, Y. Surveillance for foodborne disease outbreaks in China, 2003 to 2008. Food Control 2018, 84, 382-388. [CrossRef] 
29. Pissuwan, D.; Gazzana, C.; Mongkolsuk, S.; Cortie, M.B. Single and multiple detections of foodborne pathogens by gold nanoparticle assays. Wiley Interdiscip. Rev. Nanomed. Nanobiotechnol. 2020, 12, e1584. [CrossRef]

30. Bolton, D.J.; Robertson, L.J. Mental health disorders associated with foodborne pathogens. J. Food Prot. 2016, 79, 2005-2017. [CrossRef]

31. Costanzo, N.; Ceniti, C.; Santoro, A.; Clausi, M.T.; Casalinuovo, F. Foodborne pathogen assessment in raw milk cheeses. Int. J. Food Sci. 2020. [CrossRef]

32. Ghatak, S. Strategies for elimination of foodborne pathogens, their influensive detection techniques and drawbacks. In Meat Quality Analysis; Academic Press: Cambridge, MA, USA, 2020; pp. 267-286.

33. Bazzoni, A.M.; Cangini, M.; Mudadu, A.G.; Lorenzoni, G.; Arras, I.; Sanna, G.; Virgilio, S. Recent findings of paralytic shellfish toxins linked to the genus Alexandrium Halim in Mediterranean mollusc production areas. Toxicon 2020, 174, 48-56. [CrossRef]

34. Khare, S.; Tonk, A.; Rawat, A. Foodborne diseases outbreak in India: A Review. Int. J. Food Sci. Nutr. 2018, 3, 9-10.

35. Mostafa, A.A.; Al-Askar, A.A.; Almaary, K.S.; Dawoud, T.M.; Sholkamy, E.N.; Bakri, M.M. Antimicrobial activity of some plant extracts against bacterial strains causing food poisoning diseases. Saudi J. Biol. Sci. 2018, 25, 361-366. [CrossRef]

36. Grutsch, A.A.; Nimmer, P.S.; Pittsley, R.H.; McKillip, J.L. Bacillus spp. as Pathogens in the Dairy Industry. In Foodborne Diseases; Academic Press: Cambridge, MA, USA, 2018; pp. 193-211.

37. Griffiths, M.W.; Schraft, H. Bacillus cereus food poisoning. In Foodborne Diseases; Academic Press: Cambridge, MA, USA, 2017; pp. 395-405.

38. Xu, Z.; Luo, Y.; Soteyome, T.; Lin, C.W.; Xu, X.; Mao, Y.; Liu, J. Rapid Detection of Food-Borne Escherichia coli O157: H7 with Visual Inspection by Crossing Priming Amplification (CPA). Food Anal. Methods 2019, 1-8. [CrossRef]

39. Kramarenko, T.; Meremäe, K.; Sõgel, J.; Kuningas, M.; Vilem, A.; Häkkinen, L.; Roasto, M. Occurence of Escherichia coli O157: H7 in Estonian dairy farms and beef production chain in 2005-2014. Agraarteadus 2018, 29, 89-94.

40. Letchumanan, V.; Loo, K.Y.; Law, J.W.F.; Wong, S.H.; Goh, B.H.; Ab Mutalib, N.S.; Lee, L.H. Vibrio parahaemolyticus: The protagonist of foodborne diseases. Prog. Microbes Mol. Biol. 2019, 2. [CrossRef]

41. Jiang, Y.; Chu, Y.; Xie, G.; Li, F.; Wang, L.; Huang, J.; Yao, L. Antimicrobial resistance, virulence and genetic relationship of Vibrio parahaemolyticus in seafood from coasts of Bohai Sea and Yellow Sea, China. Int. J. Food Microbiol. 2019, 290, 116-124. [CrossRef] [PubMed]

42. Ma, Y.; Ding, S.; Fei, Y.; Liu, G.; Jang, H.; Fang, J. Antimicrobial activity of anthocyanins and catechins against foodborne pathogens Escherichia coli and Salmonella. Food Control 2019, 106, 106712. [CrossRef]

43. Amagliani, G.; Rotundo, L.; Carloni, E.; Omiccioli, E.; Magnani, M.; Brandi, G.; Fratamico, P. Detection of Shiga toxin-producing Escherichia coli (STEC) in ground beef and bean sprouts: Evaluation of culture enrichment conditions. Food Res. Int. 2018, 103, 398-405. [CrossRef]

44. Sharma, N. Indian Based Foodborne Diseases-A Discussion. EC Microbiol. 2019, 15, 771-776.

45. Paramithiotis, S.; Drosinos, E.H.; Skandamis, P.N. Food recalls and warnings due to the presence of foodborne pathogens-A focus on fresh fruits, vegetables, dairy and eggs. Curr. Opin. Food Sci. 2017, 18, 71-75. [CrossRef]

46. Li, Y.; Pei, X.; Yan, J.; Liu, D.; Zhang, H.; Yu, B.; Yang, D. Prevalence of foodborne pathogens isolated from retail freshwater fish and shellfish in China. Food Control 2019, 99, 131-136. [CrossRef]

47. Baron, S.; Larvor, E.; Chevalier, S.; Jouy, E.; Kempf, I.; Granier, S.A.; Lesne, J. Antimicrobial susceptibility among urban wastewater and wild shellfish isolates of non-O1/Non-O139 Vibrio cholerae from La Rance Estuary (Brittany, France). Front. Microbiol. 2017, 8, 1637. [CrossRef]

48. Mesbah Zekar, F.; Granier, S.A.; Touati, A.; Millemann, Y. Occurrence of Third-Generation Cephalosporins-Resistant Klebsiella pneumoniae in fresh fruits and vegetables purchased at markets in Algeria. Microbial Drug Resist. 2019. [CrossRef] [PubMed]

49. Ghafur, A.; Shankar, C.; GnanaSoundari, P.; Venkatesan, M.; Mani, D.; Thirunarayanan, M.A.; Veeraraghavan, B. Detection of chromosomal and plasmid-mediated mechanisms of colistin resistance in Escherichia coli and Klebsiella pneumoniae from Indian food samples. J. Glob. Antimicrob. Resist. 2019, 16, 48-52. [CrossRef] [PubMed] 
50. Riley, L.W. Extraintestinal foodborne pathogens. Annu. Rev. Food Sci. Technol. 2020, 11. [CrossRef] [PubMed]

51. Skarp, C.P.A.; Hänninen, M.L.; Rautelin, H.I.K. Campylobacteriosis: The role of poultry meat. Clin. Microbiol. Infect. 2016, 22, 103-109. [CrossRef] [PubMed]

52. Hamad, G.M.; Abdelmotilib, N.M.; Darwish, A.M.; Zeitoun, A.M. Commercial probiotic cell-free supernatants for inhibition of Clostridium perfringens poultry meat infection in Egypt. Anaerobe 2020, 102181. [CrossRef]

53. Rouger, A.; Tresse, O.; Zagorec, M. Bacterial contaminants of poultry meat: Sources, species, and dynamics. Microorganisms 2017, 5, 50. [CrossRef]

54. Aston, S.J.; Beeching, N.J. “Botulism”. In Hunter's Tropical Medicine and Emerging Infectious Diseases; Content Repository; Elsevier: Amsterdam, The Netherlands, 2020; pp. 551-554.

55. Yadav, S.K.; Singh, M.; Ponmariappan, S. ELISA Based Detection of Botulinum Neurotoxin Type 'F'in Red Meat and Canned Fish. Def. Life J. 2019, 4, 226-230. [CrossRef]

56. Drali, R.; Deriet, A.; Verhaegen, B.; De Keersmaecker, S.C.J.; Botteldoorn, N.; Vanneste, K.; Mouffok, F. Whole-genome sequencing of Listeria monocytogenes serotype $4 \mathrm{~b}$ isolated from ready-to-eat lentil salad in Algiers, Algeria. New Microbes New Infect. 2020, 33, 100628. [CrossRef]

57. Vojkovska, H.; Myšková, P.; Gelbíčová, T.; Skočková, A.; Koláčková, I.; Karpíšková, R. Occurrence and characterization of food-borne pathogens isolated from fruit, vegetables and sprouts retailed in the Czech Republic. Food Microbiol. 2017, 63, 147-152. [CrossRef]

58. Nisa, I.; Qasim, M.; Yasin, N.; Ullah, R.; Ali, A. Shigella flexneri: An emerging pathogen. Folia Microbiologica 2020, 1-17. [CrossRef]

59. Shafqat, M.; Batool, A.; Kazmi, S.S. Drinking water quality, water distribution systems and human health: A microbial evaluation of drinking water sources in salt range. Int. J. Hydro. 2018, 2, 542-547. [CrossRef]

60. Bigoraj, E.; Kozyra, I.; Kwit, E.; Rzeżutka, A. Detection of hepatitis E virus (rabbit genotype) in farmed rabbits entering the food chain. Int. J. Food Microbiol. 2020, 319, 108507. [CrossRef] [PubMed]

61. Kaiser, M.; Delaune, D.; Chazouillères, O.; Blümel, J.; Roque-Afonso, A.M.; Baylis, S.A. A world health organization human hepatitis $\mathrm{E}$ virus reference strain related to similar strains isolated from rabbits. Genome Announc. 2018, 6, e00292-e00318. [CrossRef]

62. Yang, X.; Wu, Q.; Huang, J.; Wu, S.; Zhang, J.; Chen, L.; Lei, T. Prevalence and characterization of Salmonella isolated from raw vegetables in China. Food Control 2020, 109, 106915. [CrossRef]

63. Saw, S.H.; Mak, J.L.; Tan, M.H.; Teo, S.T.; Tan, T.Y.; Cheow, M.Y.K.; Son, R. Detection and quantification of salmonella in fresh vegetables in perak, Malaysia. Food Res. 2020, 4, 441-448. [CrossRef]

64. World Health Organization (WHO). To Improve Nutrition, Food Safety and Food Security, throughout the Life-Course, and in Support of Public Health and Sustainable Development; WHO: Geneva, Switzerland, 2009.

65. Havelaar, A.H.; Brul, S.; De Jong, A.; De Jonge, R.; Zwietering, M.H.; Ter Kuile, B.H. Future challenges to microbial food safety. Int. J. Food Microbiol. 2010, 139, S7-S94. [CrossRef]

66. Anonymous. Regulation (EC) No 178/2002 of the European Parliament and of the Council of 28 January 2002 laying down the general principles and requirements of food law, establishing the European Food Safety Authority and laying down procedures in matters of food safety. Off. J. Eur. Commun. 2002, 31, 1-24.

67. Öz, P.; Arun, Ö.Ö. Evaluating the performance of ATP bioluminescence method by comparison with classical cultural method. Food Health 2019, 5, 77-82. [CrossRef]

68. Silvestri, E.E.; Yund, C.; Taft, S.; Bowling, C.Y.; Chappie, D.; Garrahan, K.; Nichols, T.L. Considerations for estimating microbial environmental data concentrations collected from a field setting. J. Expo. Sci. Environ. Epidemiol. 2017, 27, 141-151. [CrossRef]

69. González-Ferrero, C.; Irache, J.M.; Marín-Calvo, B.; Ortiz-Romero, L.; Virto-Resano, R.; González-Navarro, C.J. Encapsulation of probiotics in soybean protein-based microparticles preserves viable cell concentration in foods all along the production and storage processes. J. Microencapsul. 2020, 1-12. [CrossRef]

70. Sakamoto, C.; Yamaguchi, N.; Nasu, M. Rapid and simple quantification of bacterial cells by using a microfluidic device. Appl. Environ. Microbiol. 2005, 71, 1117-1121. [CrossRef] [PubMed]

71. Mobed, A.; Baradaran, B.; de la Guardia, M.; Agazadeh, M.; Hasanzadeh, M.; Rezaee, M.A.; Hamblin, M.R. Advances in detection of fastidious bacteria: From microscopic observation to molecular biosensors. TrAC Trends Anal. Chem. 2019. [CrossRef]

72. Hazan, R.; Que, Y.A.; Maura, D.; Rahme, L.G. A method for high throughput determination of viable bacteria cell counts in 96-well plates. BMC Microbiol. 2012, 12, 259. [CrossRef] [PubMed] 
73. Ikonen, J.; Pitkänen, T.; Miettinen, I.T. Suitability of optical, physical and chemical measurements for detection of changes in bacterial drinking water quality. Int. J. Environ. Res. Public Health 2013, 10, 5349-5363. [CrossRef] [PubMed]

74. Shen, Z.; Hou, N.; Jin, M.; Qiu, Z.; Wang, J.; Zhang, B.; Li, J. A novel enzyme-linked immunosorbent assay for detection of Escherichia coli O157: H7 using immunomagnetic and beacon gold nanoparticles. Gut Pathog. 2014, 6, 14. [CrossRef] [PubMed]

75. Preechakasedkit, P.; Siangproh, W.; Khongchareonporn, N.; Ngamrojanavanich, N.; Chailapakul, O. Development of an automated wax-printed paper-based lateral flow device for alpha-fetoprotein enzyme-linked immunosorbent assay. Biosens. Bioelectron. 2018, 102, 27-32. [CrossRef] [PubMed]

76. Guo, R.; McGoverin, C.; Swift, S.; Vanholsbeeck, F. A rapid and low-cost estimation of bacteria counts in solution using fluorescence spectroscopy. Anal. Bioanal. Chem. 2017, 409, 3959-3967. [CrossRef]

77. Annenkov, V.V.; Zelinskiy, S.N.; Pal'shin, V.A.; Larina, L.I.; Danilovtseva, E.N. Coumarin based fluorescent dye for monitoring of siliceous structures in living organisms. Dye Pigment. 2019, 160, 336-343. [CrossRef]

78. Ou, F.; McGoverin, C.; Swift, S.; Vanholsbeeck, F. Absolute bacterial cell enumeration using flow cytometry. J. Appl. Microbiol. 2017, 123, 464-477. [CrossRef]

79. Adan, A.; Alizada, G.; Kiraz, Y.; Baran, Y.; Nalbant, A. Flow cytometry: Basic principles and applications. Crit. Rev. Biotechnol. 2017, 37, 163-176. [CrossRef]

80. Bapat, P.; Nandy, S.K.; Wangikar, P.; Venkatesh, K.V. Quantification of metabolically active biomass using methylene blue dye reduction test (MBRT): Measurement of CFU in about 200 s. J. Microbiol. Methods 2006, 65, 107-116. [CrossRef] [PubMed]

81. Pawar, J.; Henry, R.; Viswanathan, P.; Patwardhan, A.; Singh, E.A. Testing of antibacterial efficacy of CuO nanoparticles by methylene blue reduction test against Bacillus cereus responsible for food spoilage and poisoning. Indian Chem. Eng. 2019, 61, 248-253. [CrossRef]

82. Fricke, C.; Harms, H.; Maskow, T. Rapid Calorimetric Detection of Bacterial Contamination: Influence of the Cultivation Technique. Front. Microbiol. 2019, 10, 2530. [CrossRef] [PubMed]

83. Broga, M.; Price, P.; Smith, S. Automatic Isothermal Titration Microcalorimeter Apparatus and Method of Use. U.S. Patent Application No.16/287,498, 2020.

84. Multari, R.A.; Cremers, D.A.; Dupre, J.A.M.; Gustafson, J.E. Detection of biological contaminants on foods and food surfaces using laser-induced breakdown spectroscopy (LIBS). J. Agric. Food Chem. 2013, 61, 8687-8694. [CrossRef]

85. Moncayo, S.; Manzoor, S.; Rosales, J.D.; Anzano, J.; Caceres, J.O. Qualitative and quantitative analysis of milk for the detection of adulteration by Laser Induced Breakdown Spectroscopy (LIBS). Food Chem. 2017, 232, 322-328. [CrossRef]

86. Ellis, D.I.; Broadhurst, D.; Kell, D.B.; Rowland, J.J.; Goodacre, R. Rapid and quantitative detection of the microbial spoilage of meat by Fourier transform infrared spectroscopy and machine learning. Appl. Environ. Microbiol. 2002, 68, 2822v2828. [CrossRef]

87. Johler, S.; Stephan, R.; Althaus, D.; Ehling-Schulz, M.; Grunert, T. High-resolution subtyping of Staphylococcus aureus strains by means of Fourier-transform infrared spectroscopy. Syst. Appl. Microbiol. 2016, 39, 189-194. [CrossRef]

88. Xu, Y.; Zhang, L.; Wang, C. A Rapid Detection System Design for Escherichia coli in Food Based on a Nanoprobe and Graphite Electrode Coupled with ATP Bioluminescence Technology. IEEE Access 2019, 7, 106882-106889. [CrossRef]

89. Ganjavi, M. Characterization of luminous bacteria as a biosensing element for detection of acrylamide in food. Ph.D. Dissertation, University of Maryland, College Park, MD, USA, 2014.

90. Zhang, S.B.; Zhai, H.C.; Hu, Y.S.; Wang, L.; Yu, G.H.; Huang, S.X.; Cai, J.P. A rapid detection method for microbial spoilage of agro-products based on catalase activity. Food Control 2014, 42, 220-224. [CrossRef]

91. Vigneshvar, S.; Sudhakumari, C.C.; Senthilkumaran, B.; Prakash, H. Recent advances in biosensor technology for potential applications-an overview. Front. Bioeng. Biotechnol. 2016, 4, 11. [CrossRef]

92. Rotariu, L.; Lagarde, F.; Jaffrezic-Renault, N.; Bala, C. Electrochemical biosensors for fast detection of food contaminants-trends and perspective. Trac Trends Anal. Chem. 2016, 79, 80-87. [CrossRef]

93. Wisuthiphaet, N.; Yang, X.; Young, G.M.; Nitin, N. Rapid detection of Escherichia coli in beverages using genetically engineered bacteriophage T7. AMB Express 2019, 9, 55. [CrossRef] [PubMed] 
94. Lv, X.; Huang, Y.; Liu, D.; Liu, C.; Shan, S.; Li, G.; Lai, W. Multicolor and ultrasensitive enzyme-linked immunosorbent assay based on the fluorescence hybrid chain reaction for simultaneous detection of pathogens. J. Agric. Food Chem. 2019, 67, 9390-9398. [CrossRef] [PubMed]

95. Barfidokht, A.; Gooding, J.J. Approaches toward allowing electroanalytical devices to be used in biological fluids. Electroanalysis 2014, 26, 1182-1196. [CrossRef]

96. Tilton, L.; Das, G.; Yang, X.; Wisuthiphaet, N.; Kennedy, I.M.; Nitin, N. Nanophotonic device in combination with bacteriophages for enhancing detection sensitivity of Escherichia coli in simulated wash water. Anal. Lett. 2019, 52, 2203-2213. [CrossRef]

97. Wang, Y.; Salazar, J.K. Culture-independent rapid detection methods for bacterial pathogens and toxins in food matrices. Compr. Rev. Food Sci. Food Saf. 2016, 15, 183-205. [CrossRef]

98. Hameed, S.; Xie, L.; Ying, Y. Conventional and emerging detection techniques for pathogenic bacteria in food science: A review. Trends Food Sci. Technol. 2018, 81, 61-73. [CrossRef]

99. Ali, J.; Najeeb, J.; Ali, M.A.; Aslam, M.F.; Raza, A. Biosensors: Their fundamentals, designs, types and most recent impactful applications: A review. J. Biosens. Bioelectron. 2017, 8, 1-9. [CrossRef]

100. Mayer, M.; Baeumner, A.J. A megatrend challenging analytical chemistry: Biosensor and chemosensor concepts ready for the internet of things. Chem. Rev. 2019, 119, 7996-8027. [CrossRef]

101. Ibrišimović, N.; Ibrišimović, M.; Kesić, A.; Pittner, F. Microbial biosensor: A new trend in the detection of bacterial contamination. Mon. Chem. Chem. Mon. 2015, 146, 1363-1370.

102. Qiao, Z.; Fu, Y.; Lei, C.; Li, Y. Advances in antimicrobial peptides-based biosensing methods for detection of foodborne pathogens: A review. Food Control. 2020, 107116. [CrossRef]

103. Ivnitski, D.; Abdel-Hamid, I.; Atanasov, P.; Wilkins, E. Biosensors for detection of pathogenic bacteria. Biosens. Bioelectron. 1999, 14, 599-624. [CrossRef]

104. Pellissery, A.J.; Vinayamohan, P.G.; Amalaradjou, M.A.R.; Venkitanarayanan, K. Spoilage bacteria and meat quality. In Meat Quality Analysis; Academic Press: Cambridge, MA, USA, 2020; pp. 307-334.

105. Alamer, S.; Eissa, S.; Chinnappan, R.; Herron, P.; Zourob, M. Rapid colorimetric lactoferrin-based sandwich immunoassay on cotton swabs for the detection of foodborne pathogenic bacteria. Talanta 2018, 185, 275-280. [CrossRef] [PubMed]

106. Jiao, K.; Sun, W.; Zhang, S.S. Sensitive detection of a plant virus by electrochemical enzyme-linked immunoassay. Fresenius' J. Anal. Chem. 2000, 367, 667-671. [CrossRef] [PubMed]

107. Zhao, Y.; Liu, L.; Kong, D.; Kuang, H.; Wang, L.; Xu, C. Dual amplified electrochemical immunosensor for highly sensitive detection of Pantoea stewartii sbusp. stewartii. ACS Appl. Mater. Interfaces 2014, 6, 21178-21183. [CrossRef]

108. Jarocka, U.; Wąsowicz, M.; Radecka, H.; Malinowski, T.; Michalczuk, L.; Radecki, J. Impedimetric immunosensor for detection of Plum Pox Virus in plant extracts. Electroanalysis 2011, 23, 2197-2204. [CrossRef]

109. Jarocka, U.; Radecka, H.; Malinowski, T.; Michalczuk, L.; Radecki, J. Detection of Prunus Necrotic Ringspot Virus in plant extracts with impedimetric immunosensor based on glassy carbon electrode. Electroanalysis 2013, 25, 433-438. [CrossRef]

110. Salomone, A.; Mongelli, M.; Roggero, P.; Boscia, D. Reliability of detection of Citrus tristeza virus by an immunochromatographic lateral flow assay in comparison with ELISA. J. Plant Pathol. 2004, 86, 43-48.

111. Drygin, Y.F.; Blintsov, A.N.; Grigorenko, V.G.; Andreeva, I.P.; Osipov, A.P.; Varitzev, Y.A.; Atabekov, J.G. Highly sensitive field test lateral flow immunodiagnostics of PVX infection. Appl. Microbiol. Biotechnol. 2012, 93, 179-189. [CrossRef]

112. Skottrup, P.D.; Nicolaisen, M.; Justesen, A.F. Towards on-site pathogen detection using antibody-based sensors. Biosens. Bioelectron. 2008, 24, 339-348. [CrossRef]

113. Lim, J.W.; Ha, D.; Lee, J.; Lee, S.K.; Kim, T. Review of micro/nanotechnologies for microbial biosensors. Front. Bioeng. Biotechnol. 2015, 3, 61. [CrossRef] [PubMed]

114. Bansod, B.; Kumar, T.; Thakur, R.; Rana, S.; Singh, I. A review on various electrochemical techniques for heavy metal ions detection with different sensing platforms. Biosens. Bioelectron. 2017, 94, 443-455. [CrossRef] [PubMed]

115. Chen, Y.; Guo, S.; Zhao, M.; Zhang, P.; Xin, Z.; Tao, J.; Bai, L. Amperometric DNA biosensor for Mycobacterium tuberculosis detection using flower-like carbon nanotubes-polyaniline nanohybrid and enzyme-assisted signal amplification strategy. Biosens. Bioelectron. 2018, 119, 215-220. [CrossRef] [PubMed] 
116. Sobhan, A.; Lee, J.; Park, M.K.; Oh, J.H. Rapid detection of Yersinia enterocolitica using a single-walled carbon nanotube-based biosensor for Kimchi product. LWT 2019, 108, 48-54. [CrossRef]

117. Silva, N.F.; Almeida, C.M.; Magalhães, J.M.; Gonçalves, M.P.; Freire, C.; Delerue-Matos, C. Development of a disposable paper-based potentiometric immunosensor for real-time detection of a foodborne pathogen. Biosens. Bioelectron. 2019, 141, 111317. [CrossRef] [PubMed]

118. Silva, N.F.; Magalhães, J.M.; Barroso, M.F.; Oliva-Teles, T.; Freire, C.; Delerue-Matos, C. In situ formation of gold nanoparticles in polymer inclusion membrane: Application as platform in a label-free potentiometric immunosensor for Salmonella typhimurium detection. Talanta 2019, 194, 134-142. [CrossRef]

119. Haddada, M.B.; Salmain, M.; Boujday, S. Gold colloid-nanostructured surfaces for enhanced piezoelectric immunosensing of staphylococcal enterotoxin A. Sens. Actuators B Chem. 2018, 255, 1604-1613. [CrossRef]

120. Arlett, J.L.; Myers, E.B.; Roukes, M.L. Comparative advantages of mechanical biosensors. Nat. Nanotechnol. 2011, 6, 203. [CrossRef]

121. Yu, X.; Chen, F.; Wang, R.; Li, Y. Whole-bacterium SELEX of DNA aptamers for rapid detection of E. coli O157: H7 using a QCM sensor. J. Biotechnol. 2018, 266, 39-49. [CrossRef]

122. Bayramoglu, G.; Ozalp, V.C.; Oztekin, M.; Arica, M.Y. Rapid and label-free detection of Brucella melitensis in milk and milk products using an aptasensor. Talanta 2019, 200, 263-271. [CrossRef]

123. Masdor, N.A.; Altintas, Z.; Tothill, I.E. Sensitive detection of Campylobacter jejuni using nanoparticles enhanced QCM sensor. Biosens. Bioelectron. 2016, 78, 328-336. [CrossRef] [PubMed]

124. Karczmarczyk, A.; Haupt, K.; Feller, K.H. Development of a QCM-D biosensor for Ochratoxin A detection in red wine. Talanta 2017, 166, 193-197. [CrossRef] [PubMed]

125. Shang, Q.; Su, Y.; Liang, Y.; Lai, W.; Jiang, J.; Wu, H.; Zhang, C. Ultrasensitive cloth-based microfluidic chemiluminescence detection of Listeria monocytogenes hlyA gene by hemin/G-quadruplex DNAzyme and hybridization chain reaction signal amplification. Anal. Bioanal. Chem. 2020. [CrossRef] [PubMed]

126. Kim, H.S.; Kim, Y.J.; Chon, J.W.; Kim, D.H.; Yim, J.H.; Kim, H.; Seo, K.H. Two-stage label-free aptasensing platform for rapid detection of Cronobacter sakazakii in powdered infant formula. Sens. Actuators B Chem. 2017, 239, 94-99. [CrossRef]

127. Shukla, S.; Lee, G.; Song, X.; Park, J.H.; Cho, H.; Lee, E.J.; Kim, M. Detection of Cronobacter sakazakii in powdered infant formula using an immunoliposome-based immunomagnetic concentration and separation assay. Sci. Rep. 2016, 6, 34721. [CrossRef]

128. Oh, S.Y.; Heo, N.S.; Shukla, S.; Cho, H.J.; Vilian, A.E.; Kim, J.; Huh, Y.S. Development of gold nanoparticle-aptamer-based LSPR sensing chips for the rapid detection of Salmonella typhimurium in pork meat. Sci. Rep. 2017, 7, 1-10. [CrossRef]

129. Zaraee, N.; Bhuiya, A.M.; Gong, E.S.; Geib, M.T.; Ünlü, N.L.; Ozkumur, A.Y.; Ünlü, M.S. Highly Sensitive and Label-free Digital Detection of Whole Cell E. coli with Interferometric Reflectance Imaging. arXiv 2019, arXiv:2019,1911.06950.

130. Janik, M. Development of rapid and real-time detection of pathogenic E. coli bacteria using microcavity in-line Mach-Zehnder interferometer ( $\mu \mathrm{IMZI})$. Ph.D. Thesis, Université du Québec en Outaouais, Gatineau, QB, Canada, 2019.

131. Mudgal, N.; Yupapin, P.; Ali, J.; Singh, G. BaTiO 3-Graphene-Affinity Layer-Based Surface Plasmon Resonance (SPR) Biosensor for Pseudomonas Bacterial Detection. Plasmonics 2020, 1-9. [CrossRef]

132. Zhang, P.; Chen, Y.P.; Wang, W.; Shen, Y.; Guo, J.S. Surface plasmon resonance for water pollutant detection and water process analysis. Trac Trends Anal. Chem. 2016, 85, 153-165. [CrossRef]

133. Ren, J.; He, F.; Yi, S.; Cui, X. A new MSPQC for rapid growth and detection of Mycobacterium tuberculosis. Biosens. Bioelectron. 2008, 24, 403-409. [CrossRef]

134. He, F.; Xiong, Y.; Liu, J.; Tong, F.; Yan, D. Construction of Au-IDE/CFP10-ESAT6 aptamer/DNA-AuNPs MSPQC for rapid detection of Mycobacterium tuberculosis. Biosens. Bioelectron. 2016, 77, 799-804. [CrossRef] [PubMed]

135. Ozalp, V.C.; Bayramoglu, G.; Erdem, Z.; Arica, M.Y. Pathogen detection in complex samples by quartz crystal microbalance sensor coupled to aptamer functionalized core-shell type magnetic separation. Anal. Chim. Acta 2015, 853, 533-540. [CrossRef] [PubMed]

136. Farka, Z.; Juřík, T.; Pastucha, M.; Skládal, P. Enzymatic precipitation enhanced surface plasmon resonance immunosensor for the detection of salmonella in powdered milk. Anal. Chem. 2016, 88, 11830-11836. [CrossRef] [PubMed] 
137. Wang, H.; Wang, L.; Hu, Q.; Wang, R.; Li, Y.; Kidd, M. Rapid and sensitive detection of Campylobacter jejuni in poultry products using a nanoparticle-based piezoelectric immunosensor integrated with magnetic immunoseparation. J. Food Prot. 2018, 81, 1321-1330. [CrossRef] [PubMed]

138. Masdor, N.A.; Altintas, Z.; Shukor, M.Y.; Tothill, I.E. Subtractive inhibition assay for the detection of Campylobacter jejuni in chicken samples using surface plasmon resonance. Sci. Rep. 2019, 9, 1-10. [CrossRef]

139. Pohanka, M. QCM immunosensor for the determination of Staphylococcus aureus antigen. Chem. Pap. 2020, 74, 451-458. [CrossRef]

140. Noi, K.; Iijima, M.; Kuroda, S.I.; Ogi, H. Ultrahigh-sensitive wireless QCM with bio-nanocapsules. Sens. Actuators B Chem. 2019, 293, 59-62. [CrossRef]

141. Zelada-Guillén, G.A.; Sebastián-Avila, J.L.; Blondeau, P.; Riu, J.; Rius, F.X. Label-free detection of Staphylococcus aureus in skin using real-time potentiometric biosensors based on carbon nanotubes and aptamers. Biosens. Bioelectron. 2012, 31, 226-232. [CrossRef]

142. Arora, S.; Ahmed, D.N.; Khubber, S.; Siddiqui, S. Detecting food borne pathogens using electrochemical biosensors: An overview. IJCS 2018, 6, 1031-1039.

143. Sheikhzadeh, E.; CHamsaz, M.; Turner, A.P.F.; Jager, E.W.H.; Beni, V. Label-free impedimetric biosensor for Salmonella Typhimurium detection based on poly [pyrrole-co-3-carboxyl-pyrrole] copolymer supported aptamer. Biosens. Bioelectron. 2016, 80, 194-200. [CrossRef]

144. Bagheryan, Z.; Raoof, J.B.; Golabi, M.; Turner, A.P.; Beni, V. Diazonium-based impedimetric aptasensor for the rapid label-free detection of Salmonella typhimurium in food sample. Biosens. Bioelectron. 2016, 80, 566-573. [CrossRef] [PubMed]

145. Vásquez, G.; Rey, A.; Rivera, C.; Iregui, C.; Orozco, J. Amperometric biosensor based on a single antibody of dual function for rapid detection of Streptococcus agalactiae. Biosens. Bioelectron. 2017, 87, 453-458. [CrossRef] [PubMed]

146. Arachchillaya, B.P.A.P. Development and Evaluation of a Paper Based Biochemical Sensor for Realtime Detection of Food Pathogen; Bachelor Project; Asian Institute of Technology: Khlong Luang, Thailand, 2018.

147. Hao, N.; Zhang, X.; Zhou, Z.; Hua, R.; Zhang, Y.; Liu, Q.; Qian, J.; Henan, L.; Wang, K. AgBr nanoparticles/3D nitrogen-doped graphene hydrogel for fabricating all-solid-state luminol-electrochemiluminescence Escherichia coli aptasensors. Biosens. Bioelectron. 2017, 97, 377-383. [CrossRef] [PubMed]

148. Sha, Y.; Zhang, X.; Li, W.; Wu, W.; Wang, S.; Guo, Z.; Zhou, J.; Su, X. A label-free multi-functionalized graphene oxide based electrochemiluminscence immunosensor for ultrasensitive and rapid detection of Vibrio parahaemolyticus in seawater and seafood. Talanta 2016, 147, 220-225. [CrossRef]

149. Liu, H.; Zhou, X. Paper-based bipolar electrode electrochemiluminescence (pBPE-ECL) analysis system for sensitive detection of pathogenic bacteria. Anal. Chem. 2016, 88, 10191-10197. [CrossRef]

150. Qiao, Y.; Li, J.; Li, H.; Fang, H.; Fan, D.; Wang, W. A label-free photoelectrochemical aptasensor for bisphenol A based on surface plasmon resonance of gold nanoparticle-sensitized $\mathrm{ZnO}$ nanopencils. Biosens. Bioelectron. 2016, 86, 315-320. [CrossRef]

151. Zhou, Y.; Sui, C.; Yin, H.; Wang, Y.; Wang, M.; Ai, S. Tungsten disulfide (WS 2) nanosheet-based photoelectrochemical aptasensing of chloramphenicol. Microchim. Acta 2018, 185, 453. [CrossRef]

152. Okoth, O.K.; Yan, K.; Liu, Y.; Zhang, J. Graphene-doped Bi2S3 nanorods as visible-light photoelectrochemical aptasensing platform for sulfadimethoxine detection. Biosens. Bioelectron. 2016, 86, 636-642. [CrossRef]

153. Pistelok, F.; Pohl, A.; Stuczyński, T.; Wiera, B. Using ATP tests for assessment of hygiene risks. Ecol. Chem. Eng. S 2016, 23, 259-270. [CrossRef]

154. Sharpe, A.N.; Woodrow, M.N.; Jackson, A.K. Adenosinetriphosphate (ATP) levels in foods contaminated by bacteria. J. Appl. Bacteriol. 1970, 33, 758-767. [CrossRef]

155. Mandal, P.K.; Biswas, A.K. Modern techniques for rapid detection of meatborne pathogens. In Meat Quality Analysis; Academic Press: Cambridge, MA, USA, 2020; pp. 287-303.

156. Ranjan, R.; Rastogi, N.K.; Thakur, M.S. Development of immobilized biophotonic beads consisting of Photobacterium leiognathi for the detection of heavy metals and pesticide. J. Hazard. Mater. 2012, 225, 114-123. [CrossRef] [PubMed]

157. Feng, P. Emergence of rapid methods for identifying microbial pathogens in foods. J. AOAC Int. 1996, 79, 809-812. [CrossRef] [PubMed]

158. Samkutty, P.J.; Gough, R.H.; Adkinson, R.W.; McGrew, P. Rapid assessment of the bacteriological quality of raw milk using ATP bioluminescence. J. Food Prot. 2001, 64, 208-212. [CrossRef] [PubMed] 
159. Chen, J. ATP bioluminescence: A rapid indicator for environmental hygiene and microbial quality of meats. Dairy Food Environ. Sanit. 2000, 20, 617-620.

160. Dowhanick, T.M.; Sobczak, J. ATP bioluminescence procedure for viability testing of potential beer spoilage microorganisms. J. Am. Soc. Brew. Chem. 1994, 52, 19-23. [CrossRef]

161. Ukuku, D.O.; Pilizota, V.; Sapers, G.M. Bioluminescence ATP assay for estimating total plate counts of surface microflora of whole cantaloupe and determining efficacy of washing treatments. J. Food Prot. 2001, 64, 813-819. [CrossRef]

162. Griffiths, M.W. The role of ATP bioluminescence in the food industry: New light on old problems. Food Technol. 1996, 50, 62-72.

163. Ur Rahman, U.; Shahzad, T.; Sahar, A.; Ishaq, A.; Khan, M.I.; Zahoor, T.; Aslam, S. Recapitulating the competence of novel \& rapid monitoring tools for microbial documentation in food systems. LWT-Food Sci. Technol. 2016, 67, 62-66.

164. Hyun, B.; Cha, H.G.; Lee, N.; Yum, S.; Baek, S.H.; Shin, K. Development of an ATP assay for rapid onboard testing to detect living microorganisms in ballast water. J. Sea Res. 2018, 133, 73-80. [CrossRef]

165. Mempin, R.; Tran, H.; Chen, C.; Gong, H.; Ho, K.K.; Lu, S. Release of extracellular ATP by bacteria during growth. BMC Microbiol. 2013, 13, 301. [CrossRef]

166. Fan, E.; Peng, J.; Shi, Y.; Ouyang, H.; Xu, Z.; Fu, Z. Quantification of live Gram-positive bacteria via employing artificial antibacterial peptide-coated magnetic spheres as isolation carriers. Microchem. J. 2020, 104643. [CrossRef]

167. Lomakina, G.Y.; Modestova, Y.A.; Ugarova, N.N. Bioluminescence assay for cell viability. Biochemistry 2015, 80, 701-713. [CrossRef] [PubMed]

168. Ochromowicz, K.; Hoekstra, E.J. ATP as an Indicator of Microbiological Activity in Tap Water; European Commision Directorate-General Joint Research Centre: Brussels, Belgium, 2005.

169. Shama, G.; Malik, D.J. The uses and abuses of rapid bioluminescence-based ATP assays. Int. J. Hyg. Environ. Health 2013, 216, 115-125. [CrossRef] [PubMed]

170. Libudzisz, Z.; Kowal, K.; Łódzka, P. (Eds.) Mikrobiologia Techniczna; Wydaw. PŁ.: Warsaw, Poland, 2000.

171. Luo, J.; Liu, X.; Tian, Q.; Yue, W.; Zeng, J.; Chen, G.; Cai, X. Disposable bioluminescence-based biosensor for detection of bacterial count in food. Anal. Biochem. 2009, 394, 1-6. [CrossRef]

172. Ng, L.K.; Taylor, D.E.; Stiles, M.E. Estimation of Campylobacter spp. in broth culture by bioluminescence assay of ATP. Appl. Environ. Microbiol. 1985, 49, 730-731. [CrossRef]

173. Miller, R.; Galston, G. Rapid methods for the detection of yeast and Lactobacillus by ATP bioluminescence. J. Inst. Brew. 1989, 95, 317-319. [CrossRef]

174. Pistelok, F.; Pohl, A.; Wiera, B.; Stuczyński, T. Using the ATP test in wastewater treatment in the Silesia Province. Environ. Protect. Eng. 2016, 42. [CrossRef]

175. Nelson, W.H. Physical Methods for Microorganisms Detection; CRC Press: Boca Raton, FL, USA, 2018.

176. Roady, L. The role of ATP luminometers in infection control. Infect. Control Hosp. Epidemiol. 2015, 36, 1367. [CrossRef]

177. Dostalek, P.; Branyik, T. Prospects for rapid bioluminescent detection methods in the food industry-A review. Czech J. Food Sci. 2003, 23, 85-92. [CrossRef]

178. Larson, E.L.; Aiello, A.E.; Gomez-Duarte, C.; Lin, S.X.; Lee, L.; Della-Latta, P.; Lindhardt, C. Bioluminescence ATP monitoring as a surrogate marker for microbial load on hands and surfaces in the home. Food Microbiol. 2003, 20, 735-739. [CrossRef]

179. Aycicek, H.; Oguz, U.; Karci, K. Comparison of results of ATP bioluminescence and traditional hygiene swabbing methods for the determination of surface cleanliness at a hospital kitchen. Int. J. Hyg. Environ. Health 2006, 209, 203-206. [CrossRef] [PubMed]

180. Rodrigues, L.B.; Santos, L.R.D.; Rizzo, N.N.; Ferreira, D.; Oliveira, A.P.D.; Levandowski, R.; Nascimento, V.P.D. ATP-bioluminescence and conventional microbiology for hygiene evaluation of cutting room surfaces in poultry slaughterhouse. Acta scientiae veterinariae. Porto Alegre. 2018, 46, 1-6.

181. Bakke, M.; Suzuki, S. Development of a novel hygiene monitoring system based on the detection of total adenylate (ATP+ ADP+ AMP). J. Food Prot. 2018, 81, 729-737. [CrossRef] [PubMed]

182. Ziyaina, M.; Govindan, B.N.; Rasco, B.; Coffey, T.; Sablani, S.S. Monitoring shelf life of pasteurized whole milk under refrigerated storage conditions: Predictive models for quality loss. J. Food Sci. 2018, 83, 409-418. [CrossRef] 
183. Magan, N.; Pavlou, A.; Chrysanthakis, I. Milk-sense: A volatile sensing system recognises spoilage bacteria and yeasts in milk. Sens. Actuators B: Chem. 2001, 72, 28-34. [CrossRef]

184. Law, J.W.F.; Ab Mutalib, N.S.; Chan, K.G.; Lee, L.H. Rapid methods for the detection of foodborne bacterial pathogens: Principles, applications, advantages and limitations. Front. Microbiol. 2015, 5, 770. [CrossRef]

185. Moore, G.; Griffith, C.; Fielding, L. A comparison of traditional and recently developed methods for monitoring surface hygiene within the food industry: A laboratory study. Dairy Food Environ. Sanit. 2001, 21, 478-488.

186. Kračmarová, M.; Stiborová, H.; Horáčková, Š.; Demnerová, K. Rapid detection of microbial contamination in UHT milk: Practical application in dairy industry. Czech J. Food Sci. 2018, 36, 357-364.

187. Jay, J.M.; Loessner, M.J.; Golden, D.A. Modern Food Microbiology; Springer Science \& Business Media: Berlin, Germany, 2008.

188. Russell, S.M. The effect of refrigerated and frozen storage on populations of mesophilic and coliform bacteria on fresh broiler chicken carcasses. Poult. Sci. 1995, 74, 2057-2060. [CrossRef]

189. Siragusa, G.R.; Cutter, C.N.; Dorsa, W.J.; Koohmaraie, M. Use of a rapid microbial ATP bioluminescence assay to detect contamination on beef and pork carcasses. J. Food Prot. 1995, 58, 770-775. [CrossRef]

190. Cheng, Y.; Liu, Y.; Huang, J.; Li, K.; Zhang, W.; Xian, Y.; Jin, L. Combining biofunctional magnetic nanoparticles and ATP bioluminescence for rapid detection of Escherichia coli. Talanta 2009, 77, 1332-1336. [CrossRef] [PubMed]

191. Ajaykumar, V.J.; Mandal, P.K. Modern concept and detection of spoilage in meat and meat products. In Meat Quality Analysis; Academic Press: Cambridge, MA, USA, 2020; pp. 335-349.

192. Howgate, P. A review of the kinetics of degradation of inosine monophosphate in some species of fish during chilled storage. Int. J. Food Sci. Technol. 2006, 41, 341-353. [CrossRef]

193. Shim, K. Estimating Postmortem Interval by Bioluminescent Determination of ATP Content in the Muscle of Olive Flounder (Paralichthys olivaceus). J. Food Prot. 2019, 82, 703-709. [CrossRef] [PubMed]

194. Tanaka, S.; Kuroda, A.; Kato, J.; Ikeda, T.; Takiguchi, N.; Ohtake, H. A sensitive method for detecting AMP by utilizing polyphosphate-dependent ATP regeneration and bioluminescence reactions. Biochem. Eng. J. 2001, 9, 193-197. [CrossRef]

195. Gram, L. Evaluation of the bacteriological quality of seafood. Int. J. Food Microbiol. 1992, 16, 25-39. [CrossRef]

196. Chain, V.S.; Fung, D.Y. Comparison of Redigel, Petrifilm, spiral plate system, Isogrid, and aerobic plate count for determining the numbers of aerobic bacteria in selected foods. J. Food Prot. 1991, 54, 208-211. [CrossRef]

197. Miettinen, H.; Aarnisalo, K.; Salo, S.; Sjöberg, A.M. Evaluation of surface contamination and the presence of Listeria monocytogenes in fish processing factories. J. Food Prot. 2001, 64, 635-639. [CrossRef]

198. Eed, H.R.; Abdel-Kader, N.S.; El Tahan, M.H.; Dai, T.; Amin, R. Bioluminescence-sensing assay for microbial growth recognition. J. Sens. 2016. [CrossRef]

199. Sanna, T.; Dallolio, L.; Raggi, A.; Mazzetti, M.; Lorusso, G.; Zanni, A.; Leoni, E. ATP bioluminescence assay for evaluating cleaning practices in operating theatres: Applicability and limitations. BMC Infect. Dis. 2018, 18, 583. [CrossRef]

200. Farris, L.; Habteselassie, M.Y.; Perry, L.; Chen, Y.; Turco, R.; Reuhs, B.; Applegate, B. Luminescence techniques for the detection of bacterial pathogens. In Principles of Bacterial Detection: Biosensors, Recognition Receptors and Microsystems; Springer: New York, NY, USA, 2008; pp. 213-230.

201. Turner, D.E.; Daugherity, E.K.; Altier, C.; Maurer, K.J. Efficacy and limitations of an ATP-based monitoring system. J. Am. Assoc. Lab. Anim. Sci. 2010, 49, 190-195.

(C) 2020 by the authors. Licensee MDPI, Basel, Switzerland. This article is an open access article distributed under the terms and conditions of the Creative Commons Attribution (CC BY) license (http://creativecommons.org/licenses/by/4.0/). 